\title{
The role of entrepreneurs' social networks in the creation and early development of biotechnology companies ${ }^{1}$
}

\author{
Cristina de Sousa ${ }^{2}$ \\ Pedro Videira ${ }^{3}$ \\ Margarida Fontes ${ }^{4}$
}

Abstract:

The main research question addressed in this paper concerns the way entrepreneurs' social networks affect the opportunity identification and the access and mobilization of resources in a science-based field - biotechnology - facilitating the founding of new firms. For this purpose we adopted an analytical framework combining contributions from the technological entrepreneurship and the social network literature and, on this basis, we proposed: i) that entrepreneurs social networks, both those associated with their academic and professional trajectories and those intentionally build already having the firm as a goal, are critical to access the wide range of resources necessary to create a new firm in this type of field; ii) that different network configurations are associated with the access and mobilisation of different types of resources. We developed a methodology that combines several methods usually applied separately and that permits to assemble of a vast array of data capturing the nature and contents of a wide range of relationships. This methodology was applied to a sub-set of the Portuguese biotechnology industry - the molecular biology firms.

Globally this research provides evidence that contributes to on-going debates in the area of social networks and entrepreneurship, both at the methodological and empirical levels. At this stage the main contribution regards the development of a methodology that was found to offer important insights into the behaviour of science-based entrepreneurs in their search for key resources for firm formation. The results obtained, although still exploratory, already provide some indications concerning the conditions for biotechnology entrepreneurship in countries that are peripheral relative to the major concentrations of biotechnology knowledge and business.

Keywords: Scientific entrepreneurship; Social capital; Resource access; Social Network Analysis; Biotechnology

\footnotetext{
${ }^{1}$ Research conducted in the context the ENTSOCNET project “Academic entrepreneurship, from knowledge creation to knowledge diffusion” (POCI/ESC/60500), funded by the Fundação para a Ciência e Tecnologia, whose support is gratefully acknowledged.

${ }^{2}$ INETI \& DINAMIA

${ }^{3}$ DINAMIA

${ }^{4}$ INETI \& DINAMIA
} 


\section{Introduction}

Research has demonstrated the continued relevance of new entrepreneurial firms for biotechnology development (Allansdottir et al, 2002; Ebers and Powell, 2007; Orsenigo, 1989). This role can be particularly important in intermediate developed countries where a good science base and highly skilled human resources are available but where large biotechnology firms are often absent (Padua et al, 2002). In this type of context, scientific entrepreneurship can be seen as a mechanism of knowledge transfer and transformation in market value through human capital mobility, emerging as a critical factor in the development of a biotechnology industry (Feldman et al, 2005; Fontes, 2007).

Previous research on the case of the Portuguese biotechnology industry has shown that entrepreneurs with a scientific background are behind a substantial proportion of new firm formation and that their firms tend to be created to apply advanced technologies or new technological knowledge acquired by their founders during their activities as scientists (Fontes, 2005a). In addition, it has been shown that the sources of the knowledge used by these entrepreneurs as basis for firm creation and early development, are both organisations located in their local/regional environment and organisations in more distant locations, the latter sometimes being as much (or even more) important than the former (Fontes, 2005b). So, while proximity to key knowledge sources remains an important asset - and therefore the presence of these sources nearby is a basic advantage for biotechnology entrepreneurs (Stuart and Sorenson, 2003) - the global nature of the knowledge in this field (Owen Smith and Powell, 2004) and the high mobility of its scientists (Musselin, 2004), means that entrepreneurs from more peripheral locations can also profit from their mobility experiences and the relationships built throughout them to identify new knowledge opportunities and to gain access to alternative sources (Saxenian and Hsu, 2001, Gilding, 2008).

However, the transformation of a technological opportunity into a marketable technology, product or service and its commercialisation requires the combination of technological and non-technological competences and resources (Autio, 1997; Mustar et al, 2006). The literature has shown that scientific entrepreneurs often lack managerial competences as well as industrial experience and contacts (Ensley and Hmieleski, 2005). Even if some teams try to integrate at least one member with some managerial competences, this type of firms will typically need to resort extensively to their environment in order to acquire non-technological assets and they may also be less well prepared to identify and select the more adequate sources and to negotiate their access (Shane and Stuart, 2002; Colombo and Piva, 2008). Thus the degree and quality of the assistance that entrepreneurs find in the environment, at these levels, is critical to successful firm formation (Van de Ven, 1993). But, as critical as the presence of a favourable environment, is the entrepreneurs' ability to activate or build the set of formal and informal relationships that can facilitate the access and effective use of available resources and competences (Johannisson, 1998).

The above discussion provides a brief outline of the conditions surrounding firm creation and early development in a science-based field, such as biotechnology, setting the background for the main argument that will be put forward in this paper. Given the type of requirements to operate in a science-based field, success in firm formation is determined by the entrepreneurs' ability to identify an attractive opportunity and to mobilize a great variety of resources, whose ease and mode of access differ considerably. The entrepreneurship literature defends that firm creation is a social process and that entrepreneurs' social networks - built along their academic, professional and personal life - have an important role in opportunity 
identification and in the access and mobilization of the resources necessary to exploit it (Walker, et al 1997). Our argument is that different types of networks may be required to mobilise different types of resources and that, therefore, entrepreneurs (or entrepreneurial teams) with diverse backgrounds and experiences - which result in networks with distinct compositions and structures - will face different resource access problems and will develop different strategies to mobilise the set of actors who can assist in their solution.

These differences concern on one hand the ease of access to specific resources. For instance, in the case of science-based firms, knowledge resources are generally easier to access than business-related resources, because knowledge networks are likely to be more developed than business networks ${ }^{5}$. But differences in terms of backgrounds and personal experiences may still exist, leading entrepreneurs to build more or less diverse sets of relationships, with impact upon their ability to encompass the whole range of resources needed to successfully create their firm (Mangematin et al, 2002; Druilhe and Garnsey, 2004). The differences also concern the mode of access to resources. In fact the channels used to gain access to one specific asset, and the strategies deployed to mobilize the actors that can support that process, can vary strongly and be once again influenced by the composition and also by the structure of the entrepreneurs' social networks (Powell et al, 1996). In these processes entrepreneurs will rely on their existing ties, but will also strive to build new relationships with actors they regard as key for the firm (Lin, 1999). The members of the existing network can be instrumental in this process, by assisting in the identification of these actors and by acting as mediators or credibilisers (Shane and Cable, 2002; Moensted, 2007).

Considering the above, the main research question examined in this paper is: how do entrepreneurs' social networks affect the opportunity identification and the access and mobilization of resources in a science-based field, facilitating the founding of new firms? This question will be addressed by reconstructing the social networks of a set of biotechnology entrepreneurial teams, and by assessing the way these networks were mobilised to solve key problems in the process of firm formation and early development: a) opportunity identification and exploration through the acquisition of tangible resources (capital, human resources and facilities); b) acquisition of scientific and technological knowledge; c) obtaining credibility and achieving mediation to sources of critical competences and resources.

The paper is organised as follows. Section 2 presents some contributions from the literature on entrepreneurship and social networks to the development of an analytical framework. Section 3 presents the methodology, providing a detailed analysis of the methods used to reconstruct the social networks and to analyse their composition and structure, as well as a brief characterisation of the empirical setting: the Portuguese biotechnology firms. Section 4 presents some preliminary results of the empirical analysis, based on the cases of 4 firms. The last section summarizes and discusses the findings.

\footnotetext{
${ }^{5}$ This may create some sector-specific regularities concerning the ease of access to certain resources. It is the way specific environments answer to these specificities and eventually compensate entrepreneurs weaknesses (through public policies or private initiatives) that make some environments more or less favourable to the development of some activities (Feldman and Francis, 2003).
} 


\section{Analytical framework}

In order to address the role of scientific entrepreneurs' social capital in the process of firm creation and growth, we combine literature on social networks and literature on technological entrepreneurship.

\subsection{The influence of social networks on entrepreneurship}

Recent research has shown the importance of the entrepreneurs' social capital in the access to several tangible and intangible resources, needed for the formation and growth of new firms (Greve \& Salaff, 2003; Singh, 2000). It can be particularly important in the case of technology based firms, given the high levels of uncertainty (both technological and market) and the frequent absence of non-technological competences that characterise them (YliRenko et al, 2001).

According to this view, entrepreneurship is a social process, embedded in social structures and thus, in order to fully understand the nature of the entrepreneurial process, we have to take into consideration the social networks built by the entrepreneurs along their academic, professional and personal life, as well as the ways entrepreneurs mobilise them to achieve their goals (Johannisson, 1998; Murray, 2004). The literature on social networks provides some additional insights towards the understanding of this process, by proposing that the structural characteristics and properties of networks affect (stimulating or constraining) the access and mobilization of resources (Walker, et al 1997).

Castilla et al. (2000) define social network as a set of nodes or actors (that can be persons or organizations) connected by a social relationship (or tie) of a specified type. Network configurations can differ, according to type of actors and the type of relations they encompass. Relations can be characterised by the type of interaction (e.g. formal vs. informal), the intensity of the tie and the content of the relation (e.g. the type of resource(s) that circulate through it).

The literature agrees on the fact that several kinds of resources are important in the entrepreneurial process (Brush et al. 2001; Mustar et al, 2006). It is equally recognised that social networks can be relevant to access and mobilise different resources critical to enterprise formation, namely: knowledge and information (Gittelman, 2007; Powell et al., 1996; Sorenson, 2005; Sorenson et al. 2003, Uzzi 1997, Van Geenhuizen, 2008); qualified human resources (Bygrave \& Timmons, 1992; Castilla et al., 2000; Granovetter, 1973; Saxenian, 1994); financial capital (Burton et al., 2002; Fried \& Hisrich, 1994; Shane \& Stuart, 2002; Uzzi, 1999); facilities (Birley, 1985); power and influence (Castilla et al., 2000; Lin, 1999); credibility and reputation (Deeds et al, 1997; Lin, 1999; Moensted, 2007; Shane \& Cable, 2002; Sorenson \& Stuart, 2001); and emotional support (Brüderl \& Preisendörfer, 1998). Social networks can also be instrumental in the identification of an opportunity (Ardichvili et al, 2003; Arenius \& De Clercq, 2004; Singh, 2000).

In the specific case of science-based entrepreneurship, we advance that the key resources are: scientific and technological knowledge (a critical asset in science-based industries); capital; human resources; reputation and credibility; information about markets, financing, regulatory processes, intellectual property; counselling in these same fields (Mustar et al, 2006; Druilhe and Garnsey, 2004; Vohora et al, 2004). The nature of the required resources provides some indications regarding the type actors that can be helpful in gaining access to them. These will 
potentially include venture capital firms, universities and research centres, firms possessing complementary assets and competences in technological and particularly in nontechnological fields, other biotechnology firms, incubation infrastructures, local/regional agencies (public or private) offering a variety of advisory and support services (Feldman et al, 2005; Stuart and Sorenson, 2003; van de Ven, 1993).

It is argued that different networks configurations will be associated with the access and mobilization of different types of resources. Differences in network configuration can be introduced by the nature of the resource (for example knowledge is accessed through networks that differ for the ones used to obtain financial capital) or by the stage of firm in the entrepreneurial process (Casson \& Giusta, 2007; Elfring \& Hulsink, 2003; Hite \& Hesterly, 2001; Larson \& Starr, 1993). Since we are only considering the first stages of this process (creation and early development), we focus on the role played by the distinct nature of the resources. Accordingly, for our purpose, it seems interesting to consider the three network types mentioned by Castilla et al. (2000): networks of access and opportunity (related to opportunity identification and exploration and obtaining tangible resources); networks of power and influence; and networks of production and innovation (where knowledge is the main resource that circulates).

\subsection{The impact of network characteristics on resource mobilisation}

Network characterization, as conducted in the social network literature, usually involves three aspects: the position occupied by different actors in the network, the network structure and the tie content. Regarding network position, it is considered that different positions, usually measured by network centrality measures, offer different opportunities for entrepreneurs to access the relevant sources of resources.

The analysis of network structure is frequently linked with some density measures, which capture the strength of a network interconnection. Despite the consensus on the importance of network structure, there is some debate over the specific effects of different network configurations. According to some authors, densely embedded networks with many strong ties - "closed networks" - are more beneficial for the entrepreneur (Coleman, 1988). In this view, dense networks and close ties generate trust and cooperation between the actors (Ahuja, 2000), facilitate the exchange high quality information (Gulati, 1998) and tacit knowledge exchange (Uzzi, 1996), and are particularly important to access scarce resources (Lovas and Sorenson, 2008). For the biotechnology case, Walker et al. (1997) find that denser networks are more advantageous in financial terms. According to other authors, however, more "open" networks with many weak ties (Granovetter, 1973) and structural holes (Burt, 1992) have more advantages, deriving from the fact that individuals can build relationships with multiple unconnected actors and explore brokerage opportunities (Burt, 1992). So, in this network configuration actors use these connections to obtain non redundant information.

Some authors try to conciliate these two perspectives, introducing the idea that the creation of a new firm may require a mix of weak and strong ties, each of them contributing in a particular way to the entrepreneurial process. So, strong ties and close networks are associated with the exchange of fine-grained information and tacit knowledge, trust-based governance, and resource cooptation, while weak ties and open networks provide access to novel information. In this perspective, entrepreneurs' networks should have a balanced combination of strong and weak ties (Uzzi, 1997), that can be difficult to obtain (Hansen, 1999). In addition, some research has shown that it is easier and cheaper to build networks 
with large numbers of weak and indirect ties. This can be a good strategy to enjoy the benefits of a bigger network, without paying the costs of network construction and maintenance (Burt, 1992). Nevertheless, the success of such strategy depends on the degree to which the benefits provided by different types of ties are similar in magnitude and content (Ahuja, 2000).

The tie content deals with the substance of the relation. In the case of firm creation such content are the resources and the activities performed to access and mobilise them. There is some evidence that, as firms evolve, there is a tendency for ties to become more complex and to include multiple relational forms (for example formal and informal) and/or to be related with more than one resource (Johannisson, 1996; Larson \& Starr, 1993). The concept of multiplex ties was introduced to take into account the fact that the same tie can be used to access more than one type of resource (Degenne e Forsé, 1994), but this theoretical concept has rarely been applied at an empirical level. In this research, we use the concept of multiplexity as a basis to understand what type of network(s) - involving different types of actors and/or relations and/or structures - are more appropriate for obtaining different resources/ combinations of resources.

Another theme that emerges from the literature and is useful to our analysis, concerns the intentionality behind the construction of the social network. Here we can distinguish between intentional and non-intentional networks. The first ones are purposefully created to achieve a given goal. In this category we find Lin's (1999) "instrumental actions related with contact resources" and Hite \& Hesterly (2001) "calculative networks". Non-intentional networks can be viewed as a by-product of the activity or trajectory of the actor: they are usually informal and do not have a particular motivation behind them. It is possible to find a similarity to Lin's (1999) "expressive actions related with accessible resources" and to the "identity-based networks” proposed by Hite \& Hesterly (2001).

Finally, it is also relevant to consider the theoretical debate about proximity, particularly geographical proximity, and its impact upon access to key resources and competences (Feldman, 1994). While accepting that geographical proximity is an important facilitator in the establishment and mobilisation of key relations, it can be argued that it is a necessary but not sufficient condition. Indeed, recent contributions propose other modes of proximity (social, organizational, technological), that can also be instrumental in the access to scarce or specialised resources and whose operation can take place at a distance (Boschma, 2005; Breschi and Lissoni, 2001). It is nevertheless relevant to take into account that distant relationships have particular features. Their search and/or use tend to be more purposive and focused, because it does not occur occasionally or without costs, rather is the result of a conscious effort to obtain some key resource. Trust is slower to build and also to nurture, since distant communication does not offer the same scope for mutual understanding and reciprocity (Morgan, 2001; Bathelt et al, 2004; Lorenz, 1999). Because this type of networks takes more time and effort to establish and maintain, there are tighter limits upon the number of distant relationships that firms are able to manage (Dahlander and McKelvey, 2005).

The contributions of the social network literature concerning the characteristics of networks and their potential impact upon the actors' behaviour, provide a useful analytical framework to address the process through which entrepreneurs' social networks influence firm formation. 


\section{Methodology}

Building on the theoretical insights described above, the research analyses the role of social networks on the creation of the new firm, by identifying the key networks, uncovering the way they were built and attempting to understand the contribution of different types of ties to the identification of an opportunity and to the mobilisation of a set of resources critical for the formation of a science-based firm. For this purpose we conducted empirical research on a subset of the Portuguese biotechnology industry: the molecular biology companies, involving 22 companies and a total of 54 entrepreneurs.

A central aspect of this research was the (re)construction of the firm social networks, encompassing both the entrepreneurial personal networks built along their academic and professional trajectories, and the intentional networks purposefully built along the start-up process. This raised several methodological challenges. The ways we addressed those challenges are presented in this section, covering data collection, network (re)construction methods and network measures.

But before concentrating in analysing the firms' networks, we will provide a brief characterisation of the research setting - the Portuguese dedicated biotechnology firms positioning our sample relative to the whole population and its evolution.

\subsection{Brief characterisation of Portuguese biotechnology firms}

The development of a biotechnology industry is a recent phenomenon in Portugal. In fact, after a period of relative stagnation when very few firms being created, there was a sudden entrepreneurial upsurge around 2003, which was maintained until this day. Nevertheless, the number of dedicated biotechnology firms (DBFs) is still relatively small: there are currently 76 firms formally in operation ${ }^{6}$ (to which can be added a growing number of firm projects in a more or less advanced stage of development), but about $80 \%$ were created from 2003 onwards. Thus several firms are still in an embryonic stage of development and only a small group of pioneers have developed their technologies/products and started introducing them into the market. As a result, the sector is still very incipient and populated by very small firms. Figure 1 presents the evolution in firm creation.

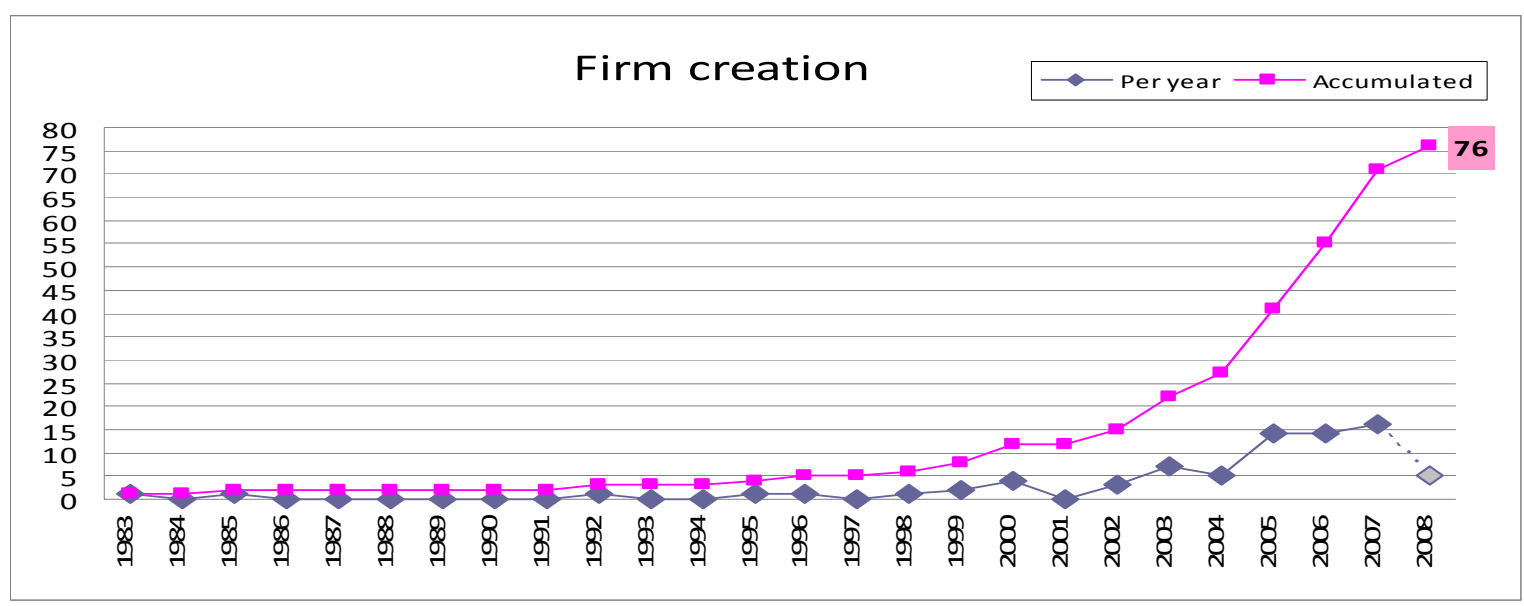

Figure 1 - Firm creation

\footnotetext{
${ }^{6}$ Firms identified up to June 2008. Include the whole population of dedicated biotechnology firms, to the best of our knowledge. Information on these firms is stored in an INETI proprietary data-base.
} 
The upsurge registered in mid-2000 was associated with a combination of favourable factors, described detail in Fontes (2007). They include: the growing quality and maturity of research in some public research organisations and the presence of a pool of highly qualified and internationalised (but often under-employed) young scientists, combined with changes in the institutional environment (involving both public and private actors), that led to a sudden increase in the incentives and support to technology-based entrepreneurial initiatives, particularly those involving the commercial exploitation of knowledge from PROs ${ }^{7}$. However, most institutional changes were directed towards the process of firm formation, and there are still serious obstacles to an effective take-off of the sector, namely in what concerns the access to resources that are critical for firms' subsequent development.

The conditions in which firm formation took place can partly explain their characteristics: the majority were direct or indirect spin-offs from research (Fontes, 2005a) and a substantial proportion involved or were created through the initiative of young scientists. Their location also reflects their origin, since it follows the main metropolitan areas where the main PROs are located and where incubation and other support infrastructures and key services are increasingly available. Thus biotechnology firms are basically distributed a along a "littoral strip", being more concentrated on and around the major towns of Lisboa and Porto, which account for half of the firms (respectively 35\% and 21\%), although there is a growing number of firms being created around Coimbra (12\%) and also Faro (9\%) and Braga (6\%) (Figure 2). The small size of the country and the good level of accessibility along this strip, makes contacts between these locations relatively easy and frequent. The main areas of application include: health (human and animal) (45\%), agriculture and food production (respectively 29\% and 16\%) and environment (8\%). It is interesting to notice that the health sector weight is relatively recent and that it includes a high proportion of firms oriented to clinical applications, although there is a growing number of firms in biopharmaceuticals.

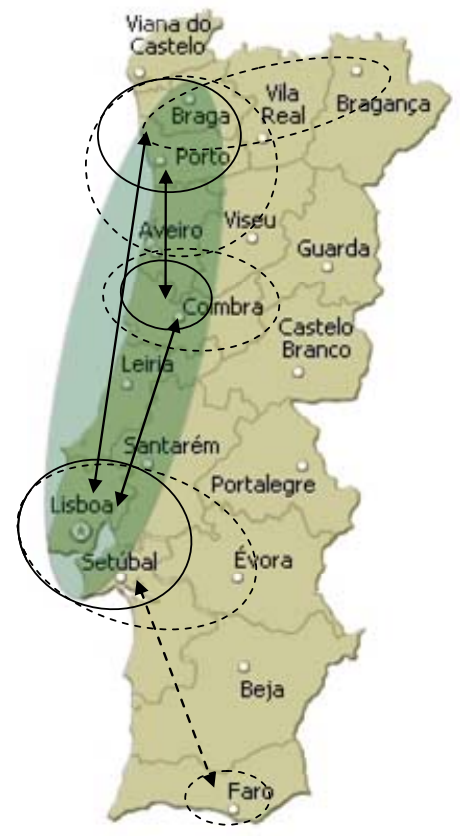

Figure 2 - Firm localisation

\footnotetext{
${ }^{7}$ There has been a low interest/investment of large developed companies in this field, which can be partly explained by the country's specialisation in sectors that are not drivers of biotechnology development. So there was a limited impact of industry-related actors in this process. One notable exception were the biotechnology entrepreneurs themselves, namely those from "pioneer” firms, who have been particularly proactive in political action on behalf of the industry and who have also shared their experience with the younger firms.
} 
The group of 22 firms that are the focus of this research - the molecular biology firms belongs almost exclusively to the younger generation (again 80\% were created from 2003 onwards). They tend to follow the above pattern although, as would be expected give the nature of the technologies being exploited, their activities tend to concentrate in the health sector (20 out of 22), with a greater predominance of clinical applications (as opposed to pharmaceuticals). Possibly for the same motive, all firms were created by entrepreneurs coming from universities or research organisations, although in several cases non-academic individuals joined the team (e.g. graduates with managerial competences, entrepreneurs, and practitioners in the application field). The teams are mostly composed of young entrepreneurs, although in some cases there is also a senior researcher in the team (who tends to retain the post in the university). In almost all firms there is at least one individual with some type of international background. A further specificity of this group of firms is the fact that they tend to be clustered in two main metropolitan areas: in the Greater Lisbon (which is responsible by the highest $R \& D$ investment in the country) (50\%) and around the town of Coimbra (27\%), a region which appears to be starting to specialise in this field ${ }^{8}$.

\subsection{Data collection}

Data about the biotechnology firms and about their entrepreneurs was collected using a combination of complementary methods, involving both search for documentary information and in-depth face-to-face interviews with the founders conducted during 2008. The former included: the Curriculum Vitae (CV) of the entrepreneurs, published data about formal collaborative projects, and a variety of documentary information about the entrepreneurs' personal trajectories and firm formation histories (including also data collected along previous research on some of the firms) ${ }^{9}$. The interviews were based on a semi-structured questionnaire and had two parts. The first focused on the entrepreneurs' personal network and on the importance of that network to firm creation process, allowing the collection of more systematic and fine grained information about the people who were important during the formation period, including the origin of the relationships and the type, nature and relevance of their respective contributions. The second addressed the firm activities, strategy and performance, with particular emphasis on innovation and technological development and on formal cooperation arrangements with other firms and with research organisations.

This combination of methods represents a novel approach, which not only provides a richer set of data, but also offers the possibility of confronting different sources and perspectives, thus improving the robustness of the data. It also allows us to separate between the existing networks and the ones mobilized during the formation process.

\subsection{Network (re)construction}

The (re)construction of social networks took several steps, which are schematically represented in Figure 1. The first one was the identification of ego-centred networks at personal (entrepreneur) level (Figure 3, STEP 1). Implicit to this step is the idea that the professional and academic trajectory of the entrepreneurs is important to access and mobilise resources critical to firm creation process. This is especially true at the early stages, when it is frequently difficult to separate the entrepreneurs’ personal network from the firm network.

\footnotetext{
${ }^{8}$ This can be explained by a tradition of research in the health area, associated with the presence of a major university hospital, an important research centre in the molecular field and, more recently, the creation of an incubator that acts as an attractor to firms in this field.

${ }^{9}$ Publication and patent data were also collected and will also be included a final version of the study.
} 
The entrepreneur's trajectory contributes both to human capital and social capital formation (Hsu, 2007). In fact, the academic and professional history not only configures the competence base and what is perceived as key sources of information and ideas, with impact on the capacity to identify new opportunities; but it also shapes the composition of the social network (in terms of actors/potential contributions), with impact upon the ability to secure the resources needed to exploit these opportunities (Burton et al., 2002).

So we have tried to reconstruct the academic and professional paths of the whole set of entrepreneurs that were part of the founding team of each firm, obtaining what we called "trajectory networks". For that purpose, we combined methods that are usually applied independently (Balconi et al. 2004; Breschi e Lissoni, 2004; Casper, 2007; Dietz et al, 2000; Murray, 2004; Singh, 2003): i) CV and project analysis were used map the individual trajectories, in order to identify the organisations where entrepreneurs had developed training or professional activities, and thus where personal relationships might have been established through time ${ }^{10}$; ii) since knowledge is a basic asset for these firms, we are currently conducting bibliometrics and patent analysis to identify key individuals along this dimension (co-authors of publications and co-inventors or co-applicants of patents), which will be included in future analysis.

The next step was to (re)construct networks at firm level (Figure 3, STEP 2). This means that we had to translate personal networks into inter-organizational networks. For this purpose we added, for each firm, the personal networks of all the members of the founding team, based on the assumption that when firms are being created their social networks are the sum of those of their entrepreneurs. Notice that since we are now adopting an organizational perspective, it is necessary to make a correspondence between the individual ties and the organization(s) in which those individuals were working. The final networks that result from the aggregation of this set of ties are labelled "potential networks".

The final step (Figure 3, STEP 3) was to build the networks that were effectively mobilised by the entrepreneurs during the creation and early development of the firm. For this purpose, we used the data gathered trough the interviews, which elicited information about the actors described by the entrepreneurs as important to identify the opportunity and to obtain the critical resources, and about their contributions. We combined this information with data on the formal partnerships, cooperation agreements and other formal relationships established by the firm up to the third year of its existence, which was collected during the firm-oriented section of the interviews. This option was based on the assumption that during the process of firm formation (that we define as the pre-start-up period and the early years) the entrepreneurs establish a number of relationships - frequently formal, or formalised at some point - which already have the firm as an explicit goal and should therefore be considered as part of the network that is mobilised by it.

\footnotetext{
${ }^{10}$ This approach is based on the assumption, that when an individual works in a given organisation he/she develops some ties that are maintained after he/she leaves, becoming part the social network (Burton et al, 2002). Our interviews confirm it for these entrepreneurs, at least for relationships abroad, which are usually regarded as more difficult to maintain through time (Dhalander and McKelvey, 2005).
} 

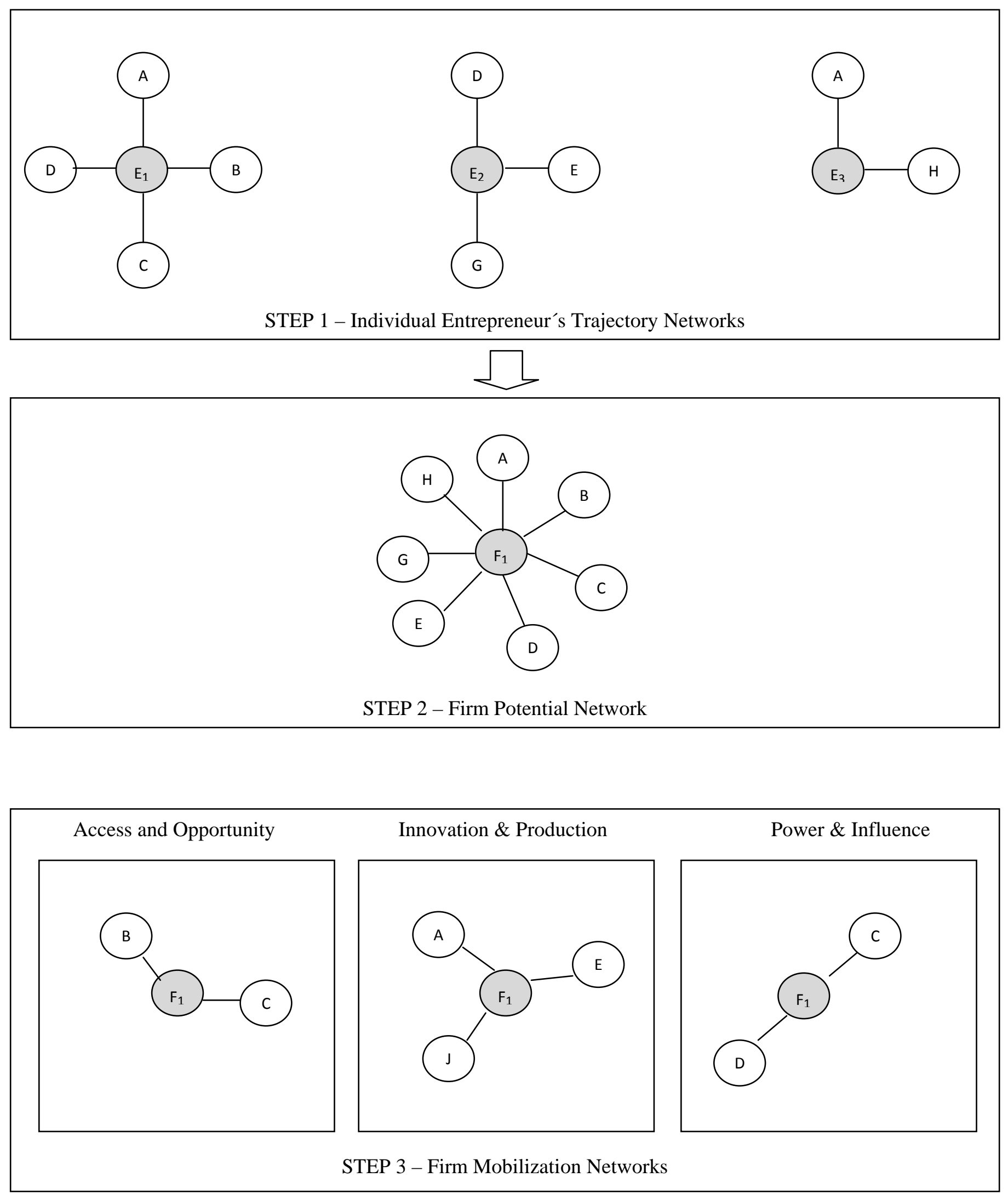

Figure 3 - Network construction 
The information was collected for different types of activities, enabling us to construct three "mobilisation networks", as suggested by Castilla et al. (2000). The actors/relationships that compose these networks could be part of the "potential network" described above or could have been formed with the intention of obtaining a particular resource.

The first mobilization network - the network of access and opportunity - is composed of all the actors/relationships used to identify the opportunity and to access and acquire the tangible resources (capital, human resources and facilities) necessary to explore it. The second mobilization network - network of innovation - includes actors/relations (formal and informal) used to obtain scientific and technological knowledge. The third mobilization network - network of power and influence - is related with the process of achieving credibility and/or using well positioned and influential individuals as mediators in the access to key resources and competences. These individuals act as "structural holes", granting access to critical actors that are not in the firm potential network and could not be mobilised without proper references.

\subsection{Network analysis}

In order to answer to our research question regarding how entrepreneurs' social networks influence the process of firm creation, we have conducted some more detailed analysis of the composition and structure of the potential and the mobilisation networks, using the methods of Social Network Analysis (Wasserman and Faust, 1994) ${ }^{11}$.

As was pointed out in section 3, network characterisation involves determining the actors' position, the network structure and the tie content. Given the nature of the networks being analysed at this stage (ego-networks with only direct ties), it does not make sense to attempt to calculate measures used to characterize actors position ${ }^{12}$. Nevertheless, given our present goals, we can compute the following measures, that will enable us to characterize the networks in terms of structure and content.

\section{Measures of network size:}

According to Burt (2000), other things being equal, bigger networks mean that an entrepreneur can receive a more diverse and complete set of resources from his network. To have bigger networks entrepreneurs must have a richer academic and/or career paths or direct more resources to network construction. Since networks are made of actors and relation, we can analyse network size considering the number of actors and the number of relations. We have considered the following measures:

1.1. Number of actors: total number of actors (including the ego) in the network.

1.2. Number of ties: total number of ties in a network.

\footnotetext{
${ }^{11}$ We used UCINET (version 6 for windows) to compute some of network measures and NetDraw to obtain network representations presented bellow.

${ }^{12}$ In other words, all actors in the network are directly related with the biotechnology firms. Thus, measures used to characterize actors' position in the network, as distance or centrality, do not make sense: our ego firm is always the most central actor and the distance between the ego and all alters is always equal to zero. To consider also indirect ties at this stage of research, we would have required to expand data collection to all alters in the network, what would represent an enormous effort. This aspect will be eliminated as research progresses and we aggregate firm networks to obtain global networks for the whole biotechnology sector.
} 
1.3. Mean (nodal) degree: mean of the number of nodes adjacent to each ego. This measure summarizes the degrees of all actors in the network, giving the mean "activity" of the network (Wasserman \& Faust, 1994).

\section{Measures of network density}

These indicators allow us to consider different network structures. Bigger networks may be beneficial, but their construction and maintenance imply effort. And network relations don't have all the same intensity, that is, in a network we have strong and weak relations that involve different time, energy and money to be developed/maintained. Networks with a big proportion of strong ties are denser. To characterise network density we have considered:

2.1. Network density (Wasserman \& Faust, 1994): proportion of possible ties that is actually present in the network. This measure corresponds to the ratio between the number of ties that are present and the maximum ties possible.

2.2. Average strength of connection between actors (Burt, 2000): computed by the ratios between the sum of all ties considering their respective strength and total number of ties.

\section{Measures of diversity of actors}

In each network, we consider several types of actors (represented by different symbols): biotechnology firms (square), firms from other sectors (diamond), venture capital organisations (up triangle), universities and research centres (circle), science \& technology parks (down triangle) and professional and trade associations (circle-in-box). To analyse the importance of each type of actor we have considered his proportion in the total number of ties.

\section{Measure of geography of relations}

To analyse the geography of relations we distinguish between three types of relations (represented in networks with different colours) local/regional (white), national non local (grey) and international (black). We have calculated the share of local actors, national (non local) actors and international actors in total firm relations for each network.

In next section we present some data and findings that result from the application of this methodology.

\section{Preliminary results}

The network analysis for the sample of 22 molecular biology firms is still on-going ${ }^{13}$. However, a complete analysis has been conducted for a group of 4 firms. Some information about these firms is presented in Table 1. This preliminary analysis enabled us to test the viability and robustness of the methodology, to fine-tune some of the methods and to evaluate its effectiveness in answering to your research question. The results are therefore still exploratory, being particularly focused on regularities that could be identified on the

\footnotetext{
${ }^{13}$ The data collection, validation, organisation and analysis is a very time consuming process, specially when firms have big and complex networks.
} 
composition and structure of the networks of this small group of firms and that might reflect modes of behaviour that are shared by this category of firms.

Table 1 - Characterisation of firms presented in case studies

\begin{tabular}{|l|c|c|c|c|}
\hline & A & B & C & D \\
\hline Year creation & 2006 & 2003 & 2007 & 2000 \\
\hline Location & Coimbra & Coimbra & Braga & Lisboa \\
\hline Field & $\begin{array}{c}\text { Health } \\
\text { (clinical) }\end{array}$ & Health (clinical) & $\begin{array}{c}\text { Health } \\
\text { (clinical) }\end{array}$ & $\begin{array}{c}\text { Health (clinical) \& } \\
\text { Food (diagnostics) }\end{array}$ \\
\hline Activity & $\begin{array}{c}\text { Technology to } \\
\text { deliver service }\end{array}$ & Service & Product & $\begin{array}{c}\text { Technology + } \\
\text { Product + Service }\end{array}$ \\
\hline $\mathbf{N}^{\text {o entrepreneurs }}$ & 2 & 5 & 2 & 3 \\
\hline Nature of entrepreneurs & $\begin{array}{c}\text { Young } \\
\text { scientists }\end{array}$ & $\begin{array}{c}\text { Young scientists } \\
+ \text { practitioners }\end{array}$ & $\begin{array}{c}\text { Young + senior } \\
\text { scientists }\end{array}$ & $\begin{array}{c}\text { Young scientists }+ \\
\text { entrepreneurs }\end{array}$ \\
\hline Entrepreneurs' origin & Foreign Univ. & $\begin{array}{c}\text { Univ. Coimbra }+ \\
\text { Foreign Univ }\end{array}$ & Univ. Minho & $\begin{array}{c}\text { FCT/UNL + small } \\
\text { biotech }\end{array}$ \\
\hline Institutional partners & $\mathrm{N}$ & Y (small firm) & PNPI & Y (small biotech) \\
\hline Venture capital (early stage) & $\mathrm{Y}$ & $\mathrm{N}$ & Negotiating & Y \\
\hline Patent applications & $\mathrm{N}$ & $\mathrm{N}$ & Y (by Univ.) & Y \\
\hline
\end{tabular}

In figures 4 to 18 (in Appendix) we have depicted four social networks for each firm. The first one corresponds to the firm potential network and the other three to the mobilization networks previously described. We have also computed the measures introduced in the previous section, which are presented in tables 2 to 5 . The analysis of those network representations and the respective measures is expected to allow us to understand:

1) What types of actors are present in each mobilisation network?

2) What types of relations are predominant (in terms of frequency, intensity, distance, nature) in each mobilization network?

3) What types of resources circulate between different types of actors and what is the importance of multiplex ties?

The contribution of the analysis to answer each of these questions is presented and discussed below.

\subsection{What types of actors are in each mobilization network?}

The data obtained for the four firms analysed here makes clear that, in firm creation processes, the entrepreneurs do not mobilised all relations in their potential network, and also that intentionally construct relations with new actors, in order to access some resources.

As previously noted, all firms have entrepreneurs who have been associated with universities or research centres, namely as young or senior scientists. This academic path is well visible in the potential network, where the university accounts for an important share, not only in terms of quantity but also in terms of intensity of ties.

However, as noted before, the transformation of a technological opportunity into a marketable technology, product or service and its commercialisation, requires the 
combination of the academic knowledge accumulated through this career path, with other (particularly non-technological) competences and resources. This means that networks related to resource mobilisation are likely more diversified in terms of actors' type. This is evident in the case of all firms, being particularly visible in network of access and opportunity, namely in the access to venture capital and facilities: there is a number of new actors, such as venture capital organisations and science \& technology parks, that were not present in firms' potential networks.

Table 2 - Firm A Network Measures

\begin{tabular}{|l|c|c|c|c|}
\hline \multicolumn{1}{|c|}{ Measure } & $\begin{array}{c}\text { Potential } \\
\text { network }\end{array}$ & $\begin{array}{c}\text { Network of } \\
\text { access and } \\
\text { opportunity }\end{array}$ & $\begin{array}{c}\text { Network } \\
\text { of } \\
\text { innovation }\end{array}$ & $\begin{array}{c}\text { Network of } \\
\text { power and } \\
\text { influence }\end{array}$ \\
\hline 1.1. No of actors & 5 & 7 & 5 & 10 \\
\hline 1.2 No of ties & 4 & 10 & 5 & 13 \\
\hline 1.3 Mean degree & 1.6 & 2.57 & 2 & 2.60 \\
\hline 2.1. Network density & 0.40 & 0.48 & 0.25 & 0.24 \\
\hline 2.2. Average strength of connection & 3.0 & 1.77 & 0.92 & 1.27 \\
\hline 3.1. \% of biotech firms & 0 & 0 & 0 & 11 \\
\hline 3.2. \% of other firms & 0 & 0 & 0 & 0 \\
\hline 3.3. \% of VC institutions & 0 & 50 & 0 & 33 \\
\hline 3.4. \% of universities & 100 & 17 & 75 & 33 \\
\hline 3.5. \% of S\&T parks & 0 & 17 & 25 & 11 \\
\hline 3.6. \% of associations & 0 & 17 & 0 & 11 \\
\hline 4.1. \% of local actors & 25 & 50 & 50 & 44 \\
\hline 4.2. \% of national actors & 50 & 50 & 25 & 56 \\
\hline 4.3. \% of international actors & 25 & 0 & 25 & 0 \\
\hline 5.1. \% of new actors & -- & 83 & 25 & 78 \\
\hline
\end{tabular}

Table 3 - Firm B Network Measures

\begin{tabular}{|l|c|c|c|c|}
\hline \multicolumn{1}{|c|}{ Measure } & $\begin{array}{c}\text { Potential } \\
\text { network }\end{array}$ & $\begin{array}{c}\text { Network of } \\
\text { access and } \\
\text { opportunity }\end{array}$ & $\begin{array}{c}\text { Network } \\
\text { of } \\
\text { innovation }\end{array}$ & $\begin{array}{c}\text { Network } \\
\text { of power } \\
\text { and } \\
\text { influence }\end{array}$ \\
\hline 1.1. No of actors & 12 & 5 & 32 & 9 \\
\hline 1.2 No of ties & 11 & 4 & 308 & 10 \\
\hline 1.3 Mean degree & 1.91 & 1.60 & 19.25 & 2.22 \\
\hline 2.1. Network density & 0.17 & 0.4 & 0.62 & 0.28 \\
\hline 2.2. Average strength of connection & 1.64 & 1.75 & 1 & 1 \\
\hline 3.1. \% of biotech firms & 9 & 0 & 23 & 38 \\
\hline 3.2. \% of other firms & 18 & 50 & 48 & 12 \\
\hline 3.3. \% of VC institutions & 0 & 0 & 0 & 0 \\
\hline 3.4. \% of universities & 36 & 50 & 19 & 38 \\
\hline 3.5. \% of S\&T parks & 0 & 0 & 3 & 0 \\
\hline 3.6. \% of associations & 36 & 0 & 7 & 12 \\
\hline 4.1. \% of local actors & 46 & 75 & 61 & 24 \\
\hline 4.2. \% of national actors & 36 & 0 & 32 & 38 \\
\hline 4.3. \% of international actors & 18 & 25 & 7 & 38 \\
\hline 5.1. \% of new actors & -- & 50 & 90 & 75 \\
\hline
\end{tabular}


Table 4 - Firm C Network Measures

\begin{tabular}{|l|c|c|c|c|}
\hline \multicolumn{1}{|c|}{ Measure } & $\begin{array}{c}\text { Potential } \\
\text { network }\end{array}$ & $\begin{array}{c}\text { Network of } \\
\text { access and } \\
\text { opportunity }\end{array}$ & $\begin{array}{c}\text { Network } \\
\text { of } \\
\text { innovation }\end{array}$ & $\begin{array}{c}\text { Network of } \\
\text { power and } \\
\text { influence }\end{array}$ \\
\hline 1.1. No of actors & 62 & 3 & 2 & -- \\
\hline 1.2 No of ties & 332 & 2 & 1 & -- \\
\hline 1.3 Mean degree & 5.35 & 1.33 & 1 & -- \\
\hline 2.1. Network density & 0.18 & 0.66 & 1 & -- \\
\hline 2.2. Average strength of connection & 1.14 & 2.5 & 1 & -- \\
\hline 3.1. \% of biotech firms & 7 & 0 & 0 & -- \\
\hline 3.2. \% of other firms & 20 & 0 & 0 & -- \\
\hline 3.3. \% of VC institutions & 0 & 0 & 0 & -- \\
\hline 3.4. \% of universities & 62 & 100 & 100 & -- \\
\hline 3.5. \% of S\&T parks & 0 & 0 & 0 & -- \\
\hline 3.6. \% of associations & 11 & 0 & 0 & -- \\
\hline 4.1. \% of local actors & 2 & 50 & 100 & -- \\
\hline 4.2. \% of national actors & 15 & 50 & 0 & -- \\
\hline 4.3. \% of international actors & 83 & 0 & 0 & - \\
\hline 5.1. \% of new actors & -- & 0 & 0 & - \\
\hline
\end{tabular}

Table 5 - Firm D Network Measures

\begin{tabular}{|l|c|c|c|c|}
\hline \multicolumn{1}{|c|}{ Measure } & $\begin{array}{c}\text { Potential } \\
\text { network }\end{array}$ & $\begin{array}{c}\text { Network of } \\
\text { access and } \\
\text { opportunity }\end{array}$ & $\begin{array}{c}\text { Network } \\
\text { of } \\
\text { innovation }\end{array}$ & $\begin{array}{c}\text { Network of } \\
\text { power and } \\
\text { influence }\end{array}$ \\
\hline 1.1. No of actors & 23 & 12 & 76 & 7 \\
\hline 1.2 No of ties & 43 & 11 & 940 & 13 \\
\hline 1.3 Mean degree & 3.74 & 1.83 & 23.64 & 4.57 \\
\hline 2.1. Network density & 0.17 & 0.17 & 0.17 & 0.62 \\
\hline 2.2. Average strength of connection & 1.16 & 1.18 & 1.01 & 1.15 \\
\hline 3.1. \% of biotech firms & 23 & 18 & 13 & 0 \\
\hline 3.2. \% of other firms & 9 & 27 & 23 & 0 \\
\hline 3.3. \% of VC institutions & 0 & 18 & 0 & 0 \\
\hline 3.4. \% of universities & 55 & 27 & 59 & 33 \\
\hline 3.5. \% of S\&T parks & 0 & 0 & 0 & 0 \\
\hline 3.6. \% of associations & 14 & 10 & 5 & 67 \\
\hline 4.1. \% of local actors & 50 & 45 & 9 & 67 \\
\hline 4.2. \% of national actors & 0 & 0 & 3 & 0 \\
\hline 4.3. \% of international actors & 50 & 55 & 88 & 33 \\
\hline 5.1. \% of new actors & -- & 82 & 96 & 67 \\
\hline
\end{tabular}

If we analyse in more detail the mobilisation networks composition in terms of actors, we notice that innovation networks are dominated by universities, which is in line with the nature of knowledge that is critical to biotechnology firms' innovation processes. Those networks appear to be build around some key organisations, already present in the potential network, mainly universities, with whom firms maintain strong relations in the process of resource mobilisation. But, it is also interesting to notice a tendency towards a more diversified structure of actors in the innovation networks, when compared to potential networks, which is achieved mainly through the integration of other firms (biotech and non biotech).

Universities also emerge as important actors in access and opportunity and in power and influence networks. In the first case, they are instrumental in opportunity identification (entrepreneurs often discuss the idea with former academic colleges or professors) and in access to human resources and facilities (especially laboratories). Regarding power and influence networks, universities play an important role in two aspects: they contribute to firm credibility and mediate their admission to new networks, as well as to people/organisations 
present in the other firm mobilisation networks. They also influence the entrepreneur's decision making process.

\subsection{What type of networks configurations predominate?}

If we observe network configurations in terms of density and tie strength, we conclude that, as expected, for the same firm, different mobilisation networks have distinct configurations. The data reveal a tendency to sparse innovation networks, when compared to other mobilisation networks. Innovation networks, which are based on knowledge flows, have small average density and small average tie strength. Besides reasons associated with the nature of the resources that circulate in this network - scientific and technological knowledge tend to be distributed by several actors, forcing firms to interact with a diverse set of organisations to obtain diverse pieces of knowledge needed in the innovation process - this detail can be explained by the fact that those networks seem to integrate a larger number of actors and, as pointed out before, it is not possible to develop and maintain strong ties with many actors.

Networks associated with opportunity identification and exploration and access to tangible resources seem to have higher levels of density and average tie strength. Based on this result, we can advance that these networks may be associated with higher levels of trust in resource access. A better understanding of the reasons behind will require a closer analysis of these ties and, namely the consideration of firm-based characteristics, such as the nature of the activity.

Other aspect of network structure is the geography of relations. Firms develop intense relations mainly with local/regional and national actors in firm creation process. This is clearly visible in all four firms' networks: lines with more width in the three mobilisation networks always appear related to local (white) or national (grey) actors.

All firms have potential ties with international actors, reflecting the international mobility of their funders. However, it is evident from the data reported in the tables, that international actors have different roles for the various firms analysed. In one case, the entrepreneurs do not mobilise international relations (either existing or intentionally built); in another they mobilise existing international relations to obtain knowledge for innovation process, but do not add new international actors to their mobilisation networks. Finally, the two other firms integrate international actors in all mobilisation networks, some of whom were not part of the potential network. Not building intentional international networks may be related with the difficulties associated with this process when balanced with availability of resources nearby.

Result may be related with the type of international background (which created more or less strong ties); with the type of activities, which may require different inputs from international actors / with the type of international actors that are compose the potential networks. A better understanding of the reasons behind these results would requires a closer analysis of this type of ties and the association with firms activities (e.g. type of markets, stage development technology for those who intend to sell mainly abroad, local availability of resources such as $\mathrm{VC})$. 


\subsection{What is the importance of multiplex ties?}

We observe that multiplex ties are present in all firms analysed. The number of multiplex ties varies from one (firm C) to seven (firm A). Those multiplex relations mean that the same actor is present in more than one mobilisation network, being associated with access to more than one resource.

Once more, universities emerge as the prime actors in multiplex relations. All firms use at least one university to access all kinds of resources: information to identify and explore the opportunity, tangible assets, knowledge and influence. These strong multiplex ties correspond to intense ties that emerge from entrepreneurs' academic and professional trajectory. We expect those actors to have higher levels of social, cultural, organisational and cognitive proximity with the biotechnology entrepreneurs.

Additionally, there seems to be an inverse relation between the size of the potential network and the number of multiplex ties: the smaller the potential networks the bigger the number of multiplex relations. This means that firms that interact with a small number of actors use these relations in a more intense way, namely to access a diversity of resources. So we can detect two possible strategies: some firms choose to extend the number of actors, with whom they develop less intense and less multiplex relations; other firms choose to have smaller networks, with more intense and multiplex relations.

\section{Discussion and implications}

The main research question addressed in this paper concerns the way entrepreneurs' social networks affect the opportunity identification and the access and mobilization of resources in a science-based field - biotechnology - facilitating the founding of new firms. For this purpose we adopted an analytical framework combining contributions from the technological entrepreneurship and the social network literature and, on this basis, we proposed: i) that entrepreneurs social networks, both those associated with their academic and professional trajectories and those intentionally build already having the firm as a goal, are critical to access the wide range of resources necessary to create a new firm in this type of field; ii) that different networks configurations are associated with the access and mobilization of different types of resources. We developed a methodology that combines several methods usually applied separately and which permits to assemble of a vast array of data capturing the nature and contents of a wide range of relationships and the multiplicity of mechanisms through which the several resources flow into the new firms. The empirical setting where this methodology was applied was the Portuguese biotechnology industry, focusing on one subset of firms - the molecular biology firms.

The data collect allowed us to reconstruct and characterize ego-centred networks for each firm. Given the rich set of information obtained, we managed to construct multiplex networks, which give us precious information about the way the entrepreneurs use their social capital to access and mobilize different kinds of resources critical for firm creation process and allowing a better understanding of the network compositions and configurations that are more effective to access the key resources in this industry. This contribution is important, since previous research has rarely addressed, simultaneously, a variety of resources and actors/relationships. 
Considering that the nature of the needed resources has implications for network composition and configuration, we have examined three different "mobilisation networks" - that is, networks that are effectively used by the firms in their search for resources: networks of access and opportunity, networks of innovation and networks of power and influence. We have compared those networks with what we labelled "potential networks", that is, the ones that result from entrepreneurs' academic and professional trajectory.

In this paper we presented some preliminary results based on the analysis four firms out of our sample of 22, which was conducted in order to test the viability, robustness and effectiveness of the methodology. These results do not encompass enough cases to enable a comparison between firms that would allow discovering differences and/or patterns along some dimensions, so they focus on some regularities of behaviour. At this level, they confirm some of our expectations and provide some insights into important features of the firms' networks, which will be further explored in subsequent analysis, covering the larger sample.

The data presented shows that, as we expected, potential and mobilisation networks are different, in the sense that they have different compositions and structures. Potential networks, which result from academic and professional career paths, are dominated by actors from universities and research centres, although there are also other actors present, with particular incidence of other biotechnology firms. In subsequent research it would be interesting to go into greater depth into these potential networks and try to analyse their degree of diversity and eventually to identify types of networks at this level. It would be also interesting to verify whether firms activate dormant relations from their potential network, as they evolve.

When entrepreneurs start to search for the resources they need to firm creation, they select only some of the members of their potential network, but, at the same time, they add new members to their social network. These new members are frequently of a different type - e.g. we witness the entrance of VC organisations and science \& technology parks that were virtually absent from the potential networks - and consequently are instrumental in accessing different resources. These include namely resources that the entrepreneurs would find more difficult to access only on the basis of their previous (largely scientific) trajectory. But there are also other situations: new members can be of the same type but provide different resources (e.g. other universities can be sources of new knowledge); the presence of new organisations may correspond in fact to the same individual actors, who moved to other organisations but kept their social ties with the entrepreneur. The extent to which potential networks are mobilised to access each type of resource may be related with the type of activity that the firm conducts, or with the human capital of the entrepreneurs. An interesting example of the latter is the case of firm $C$, which was founded by a star scientist, who acts himself as firm credibiliser. Consequently, until this moment, the firm did not need to construct a power and influence network. We expect to deepen our understanding of these aspects as research progresses.

The results also point to the fact that different mobilisation networks have different compositions and structures. This means that, as we proposed, access to different types of resources entail different types of actors and different types of relations (namely in terms of intensity and geographical distance).

An interesting finding is that, despite the diversity of actors needed to access the several resources critical to firm creation, university-based actors are strongly present in all 
mobilisation networks. The role of universities is particularly relevant in the innovation network, as would be expected, considering the type of resources that are being accessed and the nature of these firms' knowledge base. But they are also very important in power and prestige networks, which leads us to conclude that universities are not only important as sources of new knowledge, but are instrumental when firms need credentials or when mediation is critical to gain access to influential contacts.

Some additional insights were also gained regarding the way mobilisation networks are constructed. They appear to be built around a few key organisations with which firms maintain strong relations in the process of resource mobilisation. These organisations were already present in the potential network, so it is possible that strong ties based on social and/or cognitive proximity might have been developed with their members, thus providing the ground for strong support during the firm creation process. But it is also interesting to notice that, when compared to potential networks, mobilisation networks show a tendency to diversify their actor composition as firms evolve.

Finally, the results obtained regarding the association between the geographical location of the members of the social network and the intensity of ties in mobilisation networks point to the importance of local and national relations. Foreign organisations (particularly universities) are always present in the potential network, reflecting the international backgrounds of the founders. But, even among this small group of firms, there are big differences relative to the degree and mode of mobilisations of these international networks. We expect that as our research progresses we are able deepen the discussion on proximity/ distance in the access to specialised resources and in the type and contents of ties established at this level (nature, intensity).

Globally, it can be concluded that this research provides evidence that contributes to on-going debates in the area of social networks and entrepreneurship, both at the methodological and empirical levels. At this stage the main contribution regards the development of a methodology that was found offer important insights into the behaviour of science-based entrepreneurs in their search for key resources for firm formation. The results of its application to the case of biotechnology entrepreneurs in Portugal, although still exploratory, already provide some indications concerning the conditions for biotechnology entrepreneurship in countries that are in the periphery of the major concentrations of biotechnology knowledge and business. The promising results obtained so far lead us to expect that the analysis of the remaining cases in our sample and the more in-depth exploration of the very rich data obtained (which is underway), will enable us to gain a better understanding of the strategies adopted by new entrepreneurial firms to access critical resources in these particular contexts, which could contribute to inform policy formulation.

\section{References}

Allansdottir, A., Bonaccorsi A., Gambardella A., Mariani M., Orsenigo L., Pammolli F. and. Riccaboni M. (2002). Innovation and Competitiveness in the European Biotechnology Industry, Enterprise Papers $n^{\circ}$ 7, Enterprise Directorate General, European Commission.

Ardichvili, A., Cardozo, R., and Ray, S. (2003). A theory of entrepreneurial opportunity identification and development. Journal of Business Venturing, 18(1): 105-123.

Arenius, P., and De Clercq, D. (2004). A Network-Based Approach on Opportunity Recognition. Vlerick Leuven Gent Working Paper Series 2004/23 . 
Ahuja, G. (2000). Collaboration Networks, Structural Holes, and Innovation: A Longitudinal Study. Administrative Science Quarterly, 45: 425-455.

Autio, M.(1997). New, Technology-based Firms in Innovation Networks Sympletic and Generative. Research Policy, 26: 263 - 281.

Balconi M., Breschi S., Lissoni F. (2004). Networks of inventors nad the role of academia: an exploration of Italian Patent data. Research Policy, 33: 127-145.

Bathelt, H., Milberg A. and Maskell P. (2004). Clusters and Knowledge: Local Buzz, Global Pipelines and the Process of Knowledge Creation. Progress in Human Geography, 28: 3156.

Birley, S. (1985). The role of networks in the entrepreneurial process. Journal of Business Venturing, 1(1): 107-117.

Boschma, R. (2005). Proximity and Innovation: A Critical Assessment. Regional Studies, 39: 61-74.

Breschi S. and Lissoni F. (2004). Knowledge Networks from Patent Data: Methodological Issues and Research Targets. Cespri Working Paper $\mathrm{N}^{\circ} 150$.

Breschi, S. and Lissoni F. (2001). Knowledge Spillovers and Local Innovation Systems: A Critical Survey. Industrial and Corporate Change, 10: 975-1005.

Brüderl, J., and Preisendörfer, P. (1998). Network Support and the Success of Newly Founded Businesses. Small Business Economics, 10: 213-225.

Brush, C.G., Greene, P.G. and Hart, M.M. (2001). From initial idea to unique advantage: the entrepreneurial challenge of constructing a resource base. Academy of Management Executive; 15 (1): 64-78.

Burt, R. S. (2000). The network structure of social capital. In R. S. Sutton, Research in Organizational Behaviour. Greenwich: JAI Press.

Burt, R. (1992). Structural holes: The social structre of competition. Cambridge: Harvard University Press.

Burton, M. D., Sørensen, J., and Beckman, C. (2002). Coming from Good Stock: Career Histories and New Venture Formation. Research in the Sociology of Organizations, 19: 229-262.

Bygrave, W. and Timmons, J. (1992). Venture Capital and the crossroads. Boston, MA: Harvard Business School Press.

Casper S. (2007). How do technology clusters emerge and become sustainable? Social network formation and inter-firm mobility within the San Diego biotechnology cluster. Research Policy, 36: 438-455.

Casson, M., and Della Giusta, M. (2007). Entrepreneurship and Social Capital - Analysing the Impact of Social Networks on Entrepreneurial Activity from a Rational Action Perspective. International Small Business Journal, 25(3): 220-244.

Castilla E., Hwang H., Granovetter E. and Granovetter M. (2000). Social Networks in Silicon Valley. In Lee C-M, Miller W, Hancock M G, Rowen H R (eds.), The Silicon Valley edge - A habitat for innovation and entrepreneurshi. Stanford University Press, Stanford: 217247.

Coleman, J. (1988). Social Capital in the Creation of Human Capital. American Journal of Sociology, 94: 95-120.

Colombo, M. and Piva, E. (2008). Strengths and Weaknesses of Academic Startups - A Conceptual Model. IEEE Transactions On Engineering Management, 55(1): 37-49.

Dahlander, L. and Mckelvey, M. (2005). The occurrence and spatial distribution of collaboration: biotech firms in Gothenburg, Sweden. Technology Analysis and Strategic Management, 17: 409 - 432. 
Deeds, D. L., Mang, P. Y., and Frandsen, M. (1997). The quest for legitimacy: a study of biotechnology IPO's. In Reynolds, P D et al, (eds) Frontiers of Entrepreneurship Research (pp. 533-543). Babson College.

Degenne, A., and Forsé, M. (1994). Les réseaux sociaux: une analyse structurale en sociologie. Paris: Armand Colin.

Dietz, J.S., Chompalov I., Bozeman B., Lane E.O. and Park J. (2000). Using the curriculum vita to study the career paths of scientists and engineers: an exploratory assessment. Scientometrics, 49: 419-442.

Druilhe, C. and Garnsey, E. (2004) Do academic spin-outs differ and does it matter? Journal of Technology Transfer, 29 (3-4): 269-285.

Ebers, M. and Powell W. (2007). Biotechnology: Its origin, organization and outputs. Research Policy, 36: 433-437.

Elfring, T., and Hulsink, W. (2003). Networks in Entrepreneurship: The Case of Hightechnology Firms. Small Business Economic, 21: 409-422.

Ensley, M. D. and K. M. Hmieleski (2005). A comparative study of new venture top management team composition, dynamics and performance between university-based and independent start-ups. Research Policy, 34(7): 1091-1105.

Feldman, M. (1994). Knowledge Complementarity and Innovation. Small Business Economics, 6: 363-372.

Feldman, M., Francis J. and Bercovitz J. (2005). Creating a Cluster While Building a Firm: Entrepreneurs and the Formation of Industrial Clusters. Regional Studies, 39: 129-141.

Feldman, M. and Francis J. (2003) Fortune Favours the Prepared Region: The Case of Entrepreneurship and the Capitol Region Biotechnology Cluster, European Planning Studies, 11: 765-788.

Fontes, M. (2005a). The process of transformation of scientific and technological knowledge into economic value, conducted by biotechnology spin-offs. Technovation, 25: 339-347.

Fontes, M. (2005b). Distant Networking: The Knowledge Acquisition Strategies of 'OutCluster’ Biotechnology Firms. European Planning Studies, 13: 899-920.

Fontes, M. (2007). Technological entrepreneurship and capability building in biotechnology. Technology Analysis and Strategic Management, 19(3): 351-367.

Fried, V., and Hisrich, R. (1994). Toward a model of venture capital investment decision making. Financial Management, 23: 28-37.

Gilding, M. (2008). The tyranny of distance': Biotechnology networks and clusters in the Antipodes. Research Policy, 37: 1132-1144.

Gittelman M (2007). Does Geography Matter for Science-Based Firms? Epistemic Communities and the Geography of Research and patenting in Biotechnology. Organization Science, 18(4): 724-741.

Granovetter, M. (1973). The Strength of Weak Ties. American Journal of Sociology, 78: 1360-1380.

Greve, A., and Salaff, J. W. (2003). Social Networks and Entrepreneurship. Entrepreneurship Theory and Practice, 28: 1-22.

Gulati, R. (1998). Alliances and networks. Strategic Management Journal, 19: 293-317.

Hite, J., and Hesterly, W. (2001). The Evolution of Firm Networks: From Emergence to Early Growth of the Firm. Strategic Management Journal, 22: 275-286.

Hsu, D. (2007). Experienced entrepreneurial founders, organizational capital, and venture capital funding. Research Policy; 36: 722-741.

Johannisson, B. (1996). The dynamics of entrepreneurial networks. In P. e. Reynolds, Frontiers Entrepreneurship Research, pp. 253-267.

Johannisson, B. (1998). Personal Networks in Emerging Knowledge-Based Firms: Spatial and Functional Patterns. Entrepreneurship \& Regional Development, 10: 297-312. 
Larson, A., and Starr, J. A. (1993). A Network Model of Organization Formation. Entrepreneurship: Theory \& Practice, 17: 5-15.

Lin, N. (1999), Building a Network Theory of Social Capital, Connections, 22(1), 28-51.

Lorenz, E. (1999). Trust, contract and Economic Cooperation. Cambridge Journal of Economics, 23: 301-315.

Lovas, B. and Sorenson, O. (2008). The mobilization of scarce resources. In J. A. Baum, \& T. J. Rowley, Advances in Strategic Managent: Network Strategy, Vol. 25. Amsterdam: JAI Press.

Mangematin, V, Lemarié S., Boissin J.P., Catherine D., Corolleur F., Coronini R. and Trommetter M. (2002). Development of SMEs and Heterogeneity of Trajectories: The Case of Biotechnology in France. Research Policy, 32: 621-638.

Moensted, M. (2007). Strategic networking in small high tech firms. International Entreprise and Management Journal, 3: 15-27.

Morgan, K.(2001). The Exaggerated Death of Geography: Localised learning, Innovation and Uneven Development, Conference 'The Future of Innovation Studies', ECIS, 20-23 September 2001.

Murray, F. (2004). The role of academic inventors in entrepreneurial firms. Research Policy, 33: 643-659

Musselin, C. (2004). Towards a European Academic Labour Market? Some Lessons Drawn from Empirical Studies on Academic Mobility, Higher Education, 49: 55-78.

Mustar, P., Renault, M., Colombo, M., Piva, E., Fontes, M., Lockett, A. Wright, M., Clarysse, B. and Moray, N. (2006). Conceptualising the heterogeneity of research-based spin-offs: A multi-dimensional taxonomy. Research Policy, 35: 289 - 308.

Orsenigo, L. (1989). The Emergence of Biotechnology. Institutions and Markets in Industrial Innovation, London: Pinter Publishers.

Owen Smith, J. and Powell W. (2004). Knowledge Networks as Channels and Conduits: The effects of Formal Structure in the Boston Biotechnology Community. Organization Science, 15:5-21.

Pádua, M., Duarte J. and von Tunzelmann N. (2002). Biotechnology in an 'Intermediate Economy': Demand and Supply in Portugal. International Journal of Technology Management, 4: 129-151.

Powell, W., Koput, K., and Smith-Doerr, L. (1996). Interorganizational Collaboration and the Locus of Innovation: Networks of Learning in Biotecnology. Administrative Science Quarterly, 41: 116-145.

Pryke, M., and Lee, R. (1995). Place your bets: towards an understanding of globalisation, socio-financial engineering and competition within a financial centre. Urban Studies, 32(2): 329-344.

Saxenian A-L (1994). Regional Advantage. Harvard University Press, Cambridge.

Saxenian, A. and Hsu J-Y. (2001). The Silicon Valley-Hsinchu Connection: Technical Communities and Industrial Upgrading. Industrial and Corporate Change, 10: 893- 920.

Shane, S., and Cable, D. (2002). Network Ties, Reputation and the Financing of New Ventures. Management Science, 48(3), 364-381.

Shane, S., and Stuart, T. (2002). Organizational endowments and the performance. Management Science, 48: 154-170.

Singh, J. (2003). Inventor Mobility and Social Networks as Drivers of Knowledge Diffusion. [ http://www.people.hbs.edu/jsingh/academic/papers.html - Last Accessed 6/5/2008]

Singh, R. P. (2000). Entrepreneurial opportunity recognition through social networks, London: Garland. 
Sorenson, O. (2005). Social Networks, Informational Complexity and Industrial Geography. In D. Fornahl, C. Zellner, and D. A. Audretsch, The Role of Labour Mobility and Informal Networks for Knowledge Transfer (pp. 79-96). Bloomington: ISEN, Springer.

Sorenson, O., and Stuart, T. (2001). Syndication networks and the spatial distribution of venture capital investments. American Journal of Sociology, 106: 1546-1588.

Sorenson, O., Rivkin, J., and Fleming, L. (2003). Complexity, networks and knowledge flow. Harvard Business School Strategy Working Paper Series, No. 02-09.

Stuart, T. and Sorenson O. (2003). The Geography of Opportunity: Spatial Heterogeneity in Founding Rates and the Performance ob Biotechnology Firms. Research Policy, 32: 229253.

Uzzi, B. (1996). The sources and consequences of embeddedness for economic performance of organizations. American Sociological Review, 61: 674-698.

Uzzi, B. (1997). Social structure and competition in interfirm networks: the paradox of embeddedness. Administrative Science Quarterly, 42: 35-67.

Uzzi, B. (1999). Embeddedness in the making of financial capital: how social relations and networks benefit firms seeking financing. American Sociological Review, 64: 481-505.

Van de Ven, A.H. (1993). The Development of an Infrastructure for Entrepreneurship. Journal of Business Venturing, 8: 211 - 230

Van Geenhuizen M (2008). Knowledge networks of young innovators in the urban economy: biotechnology as a case study. Entrepreneurship and Regional Development, 20: 161-183.

Vohora, A., Wright, M. and Lockett, A. (2004). Critical junctures in the growth in university high-tech spinout companies. Research Policy, 33: 147-175.

Walker, G., Kogut, B., Shan, W. (1997). Social Capital Structural Holes and the Formation of an Industry Network. Organization Science, 8: 109-125.

Wasserman, S., and Faust, K. (1994). Social Network Analysis: Methods and Applications. Cambridge: Cambridge University Press.

Yli-Renko, H., Autio, E., and Sapienza, H. (2001). Social Capital, Knowledge Acquisition and Knowledge Exploitation in Young Technology-Based Firms. Strategic Management Journal, 22: 587-613. 
APPENDIX

FIRM A

Figure 4 - Potential Network:

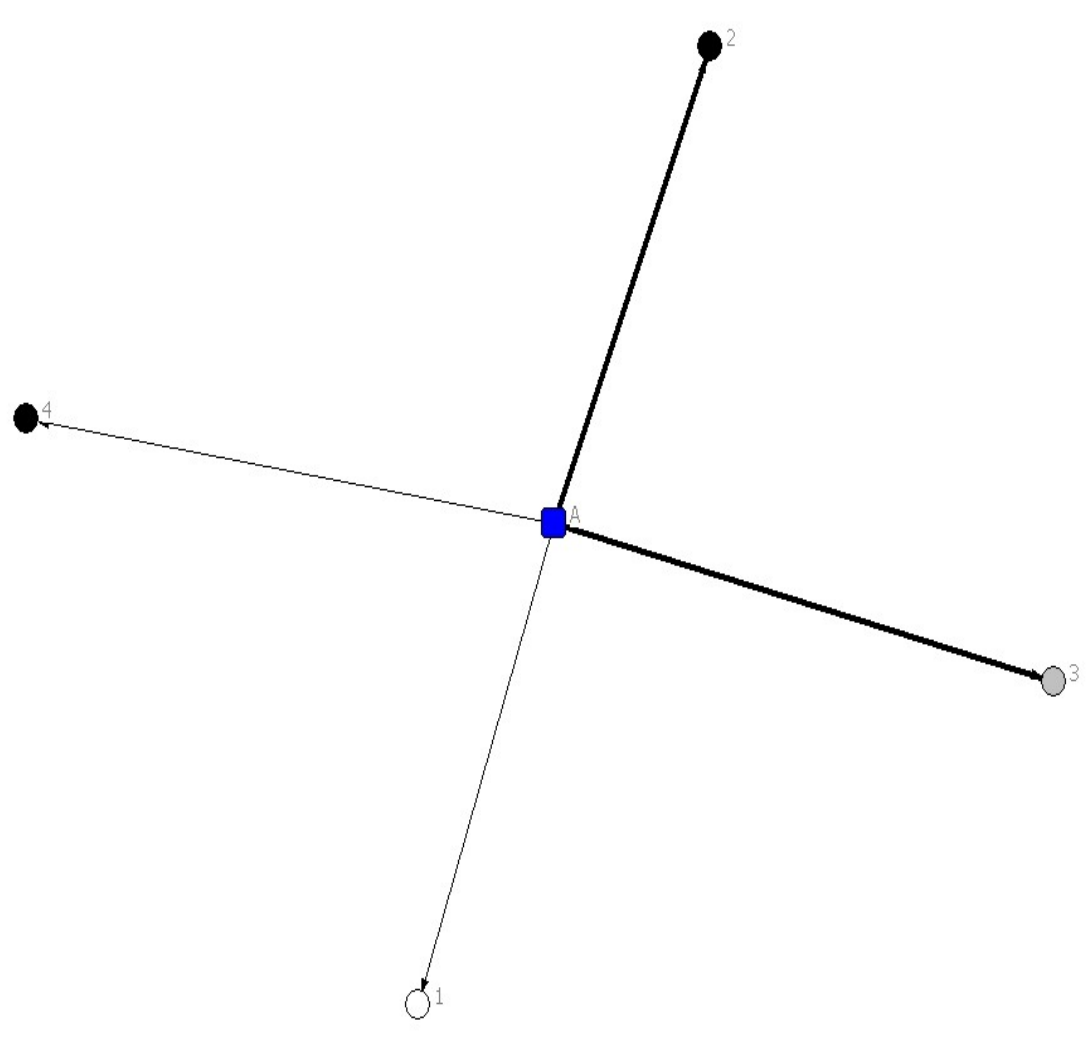

Figure 5 - Network of access and opportunity:

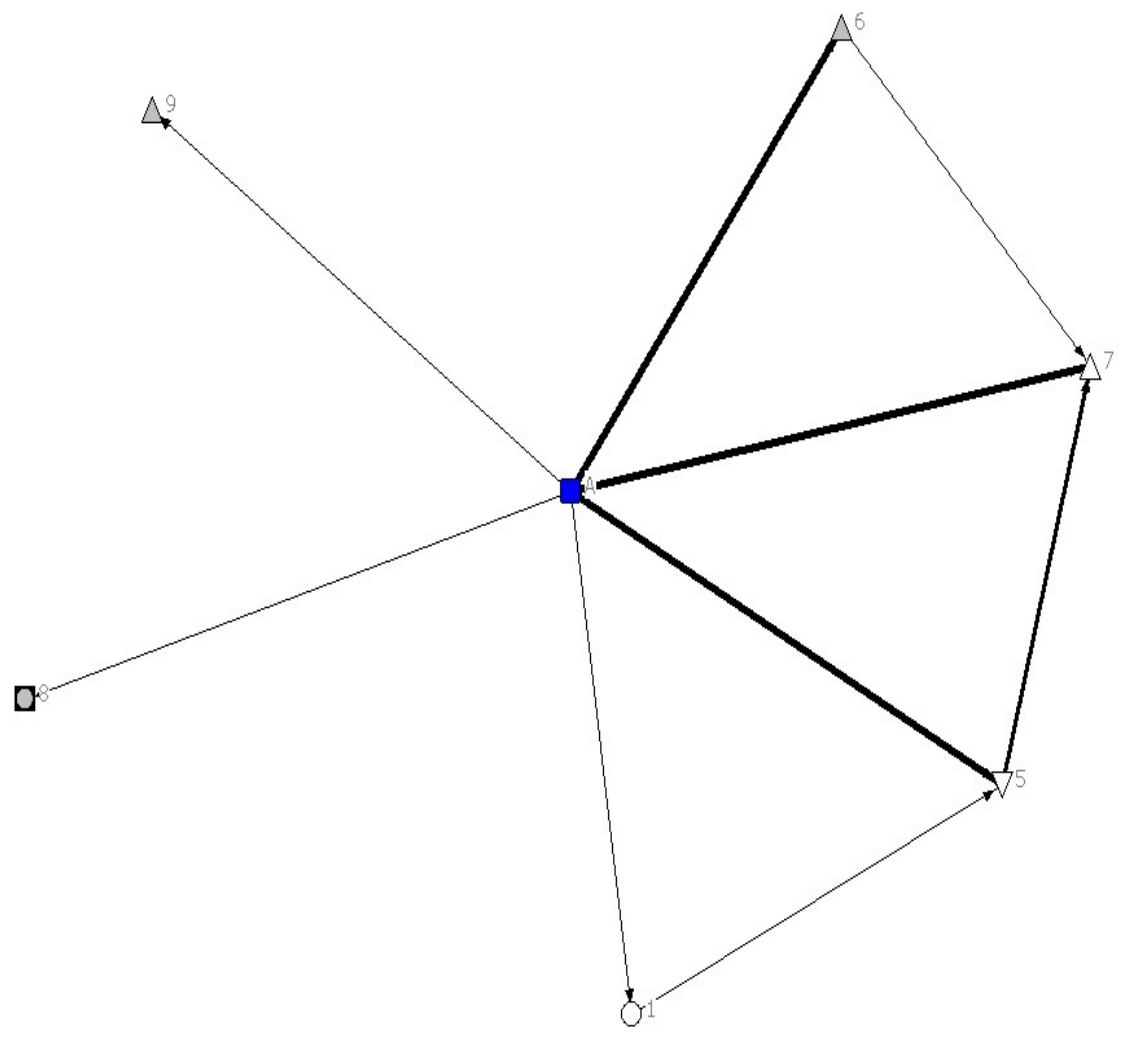


Figure 6- Network of Innovation:

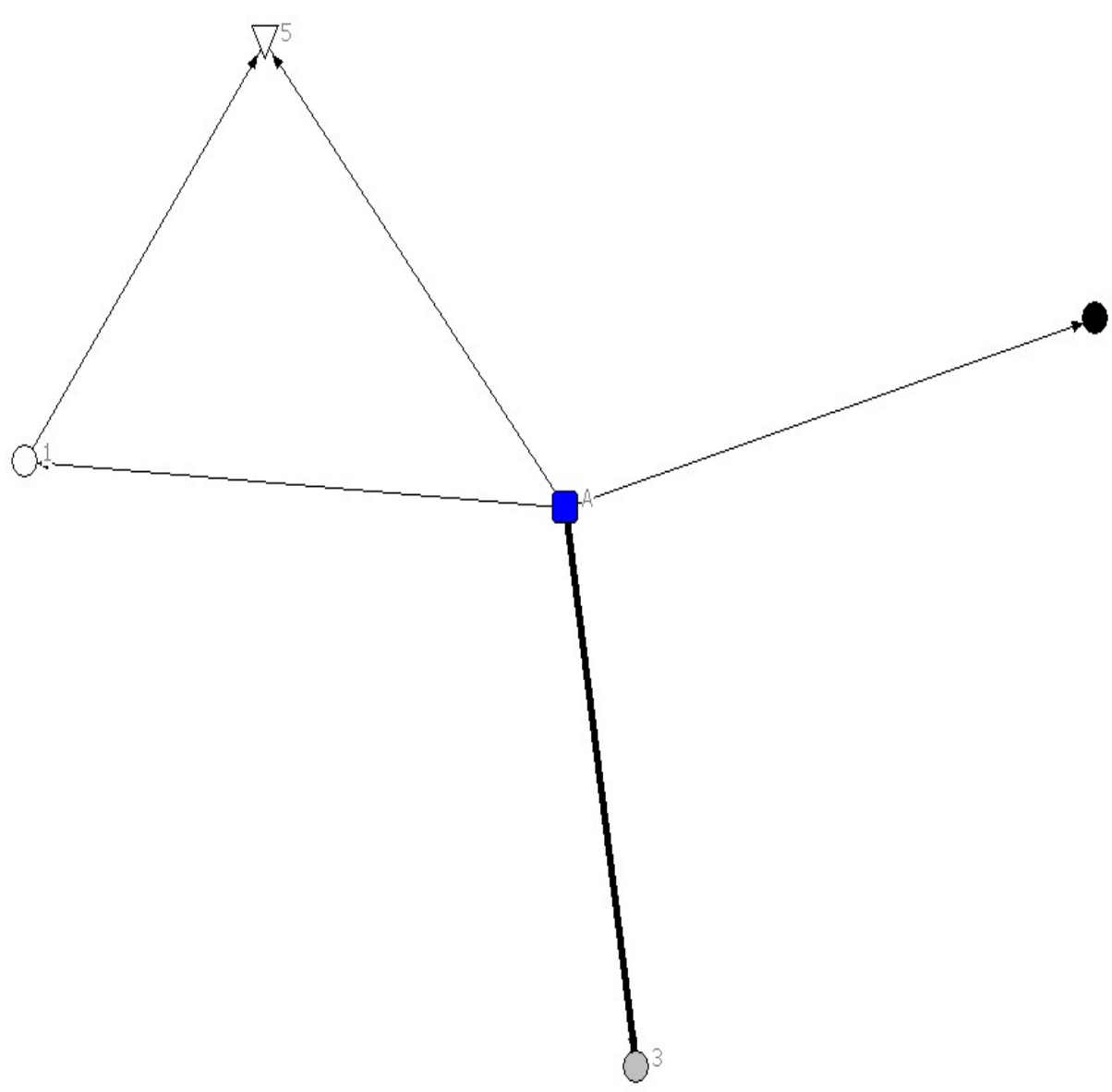

Figure 7 - Network of Power and Influence:

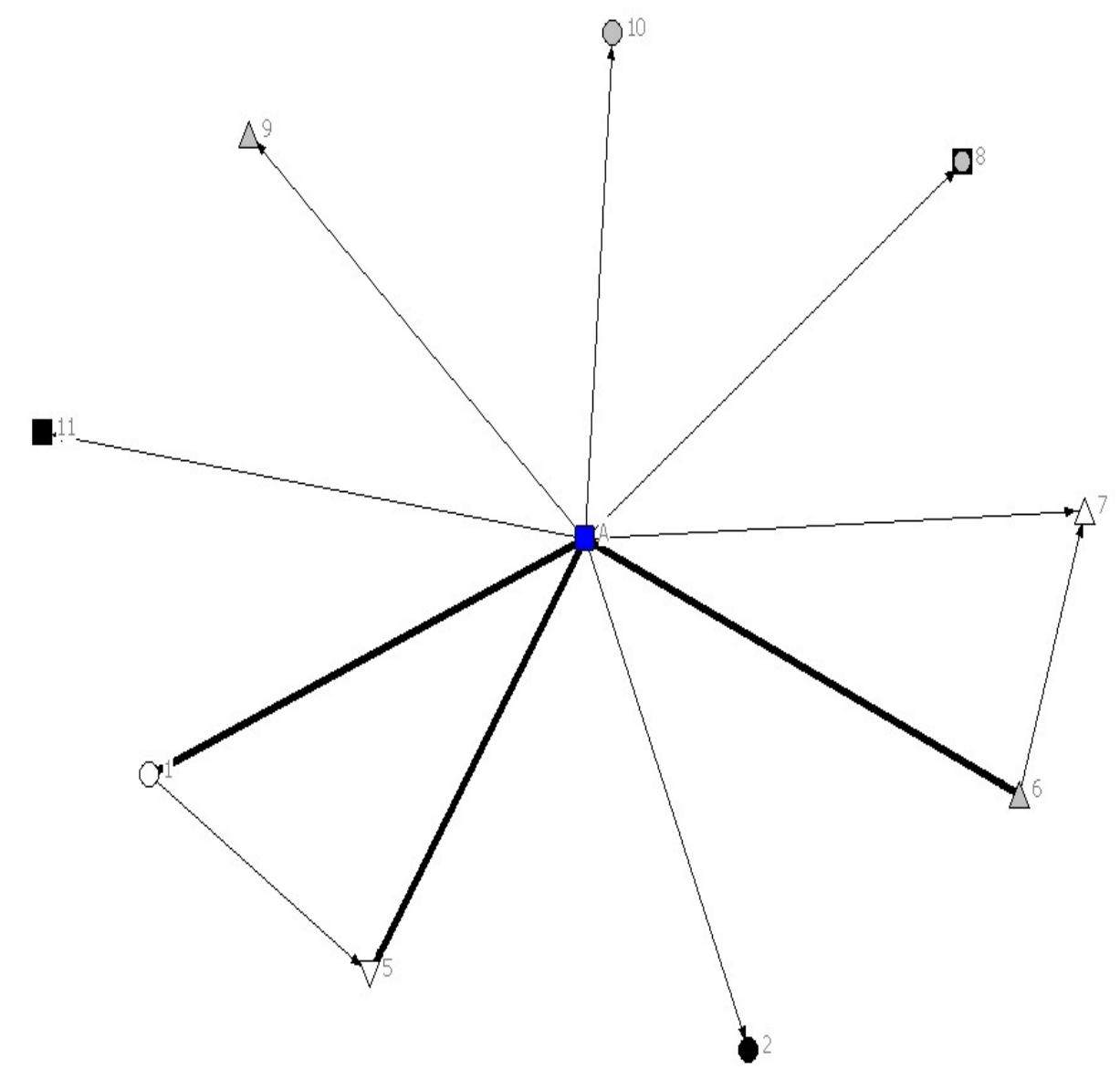


27

FIRM B

Figure 8 - Potential Network:

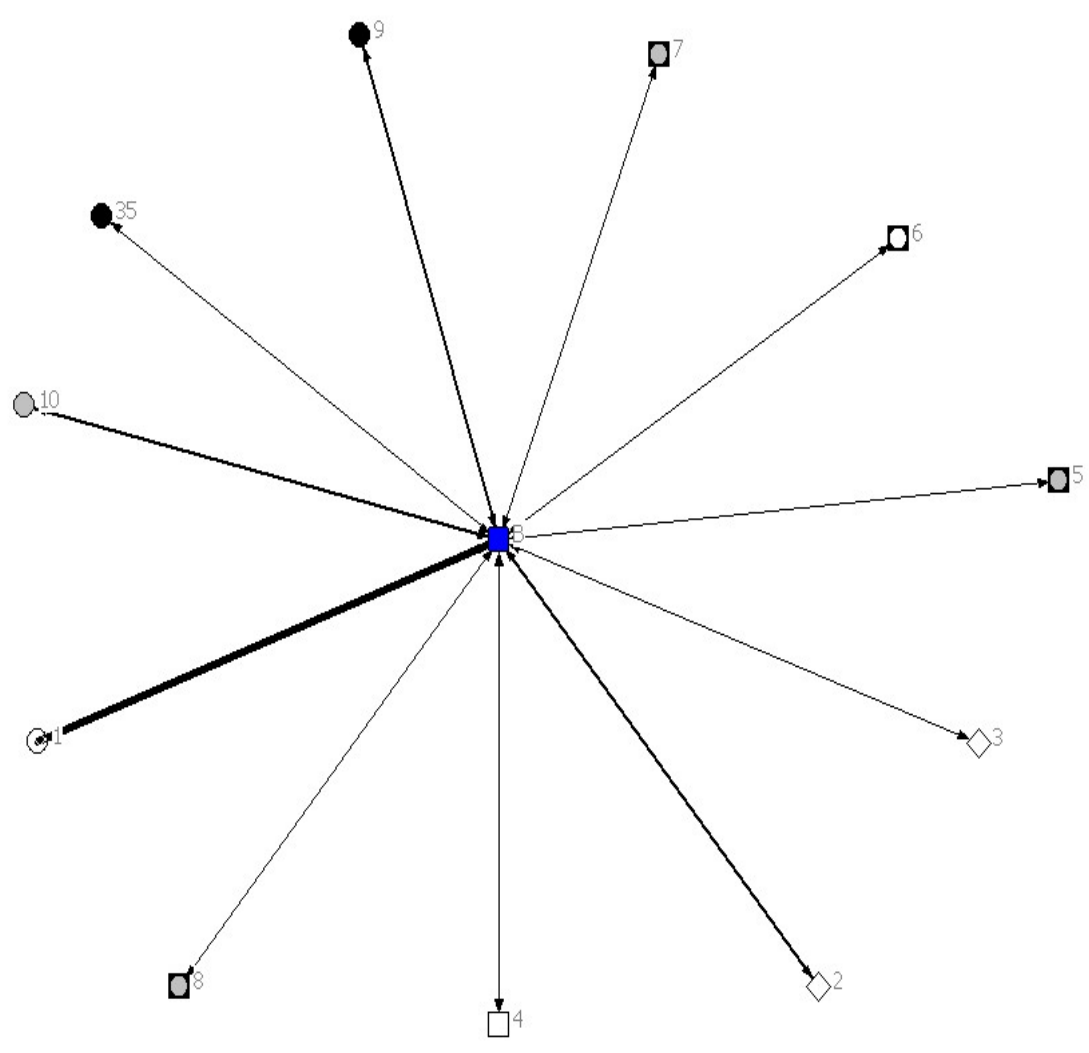

Figure 9 - Network of access and opportunity:

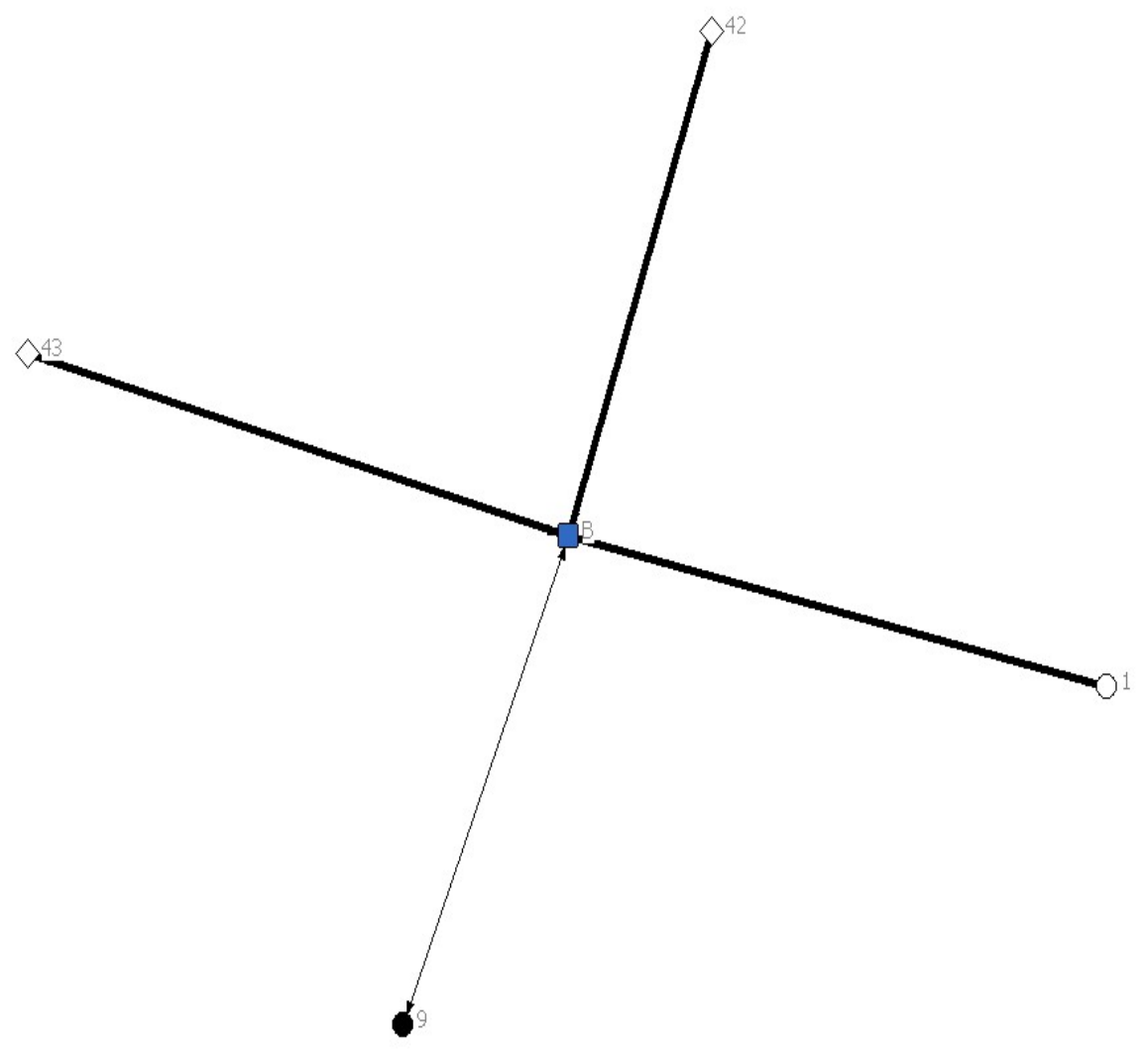


Figure 10 - Network of Innovation:

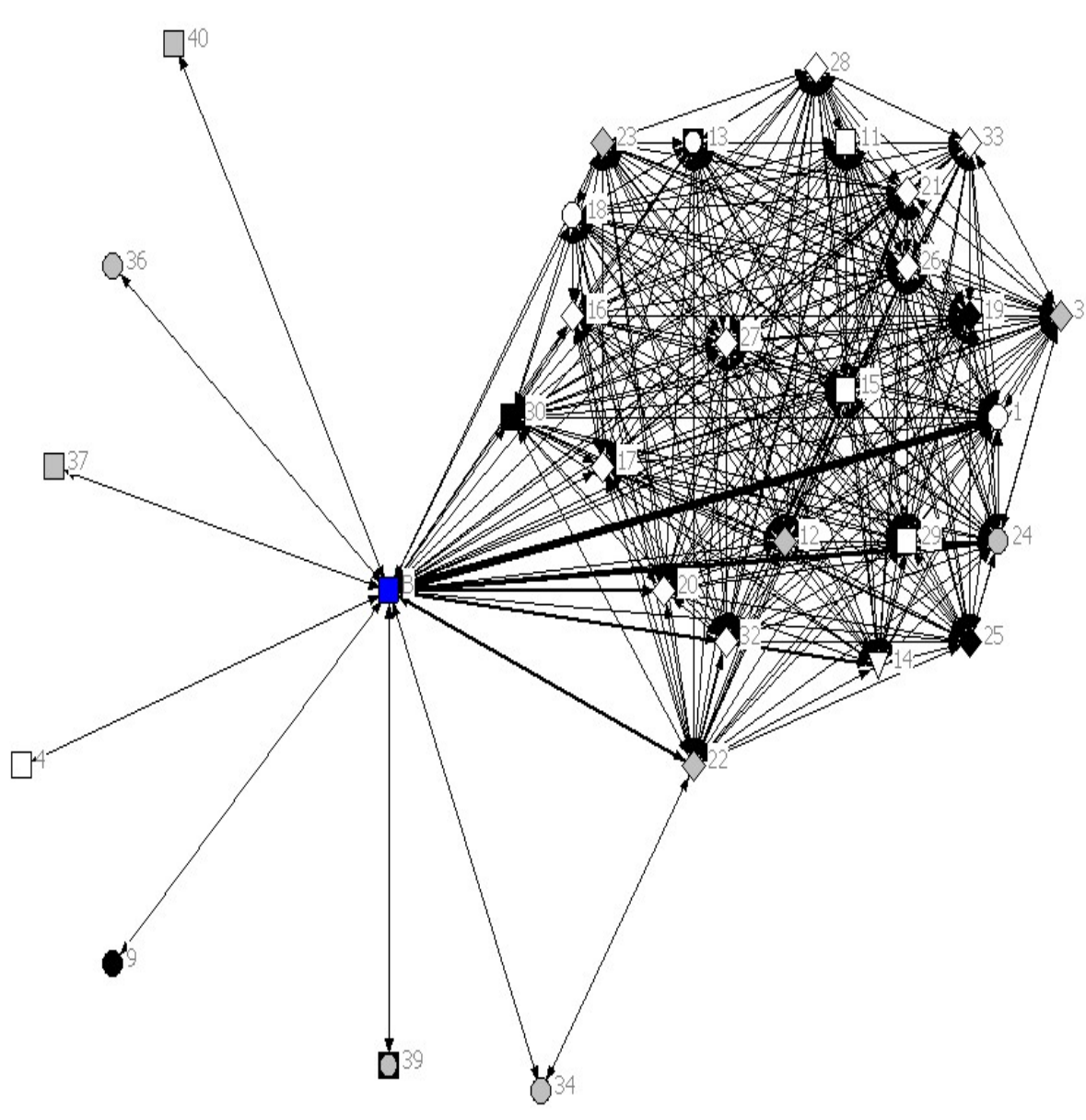

Figure 11 - Network of Power and Influence:

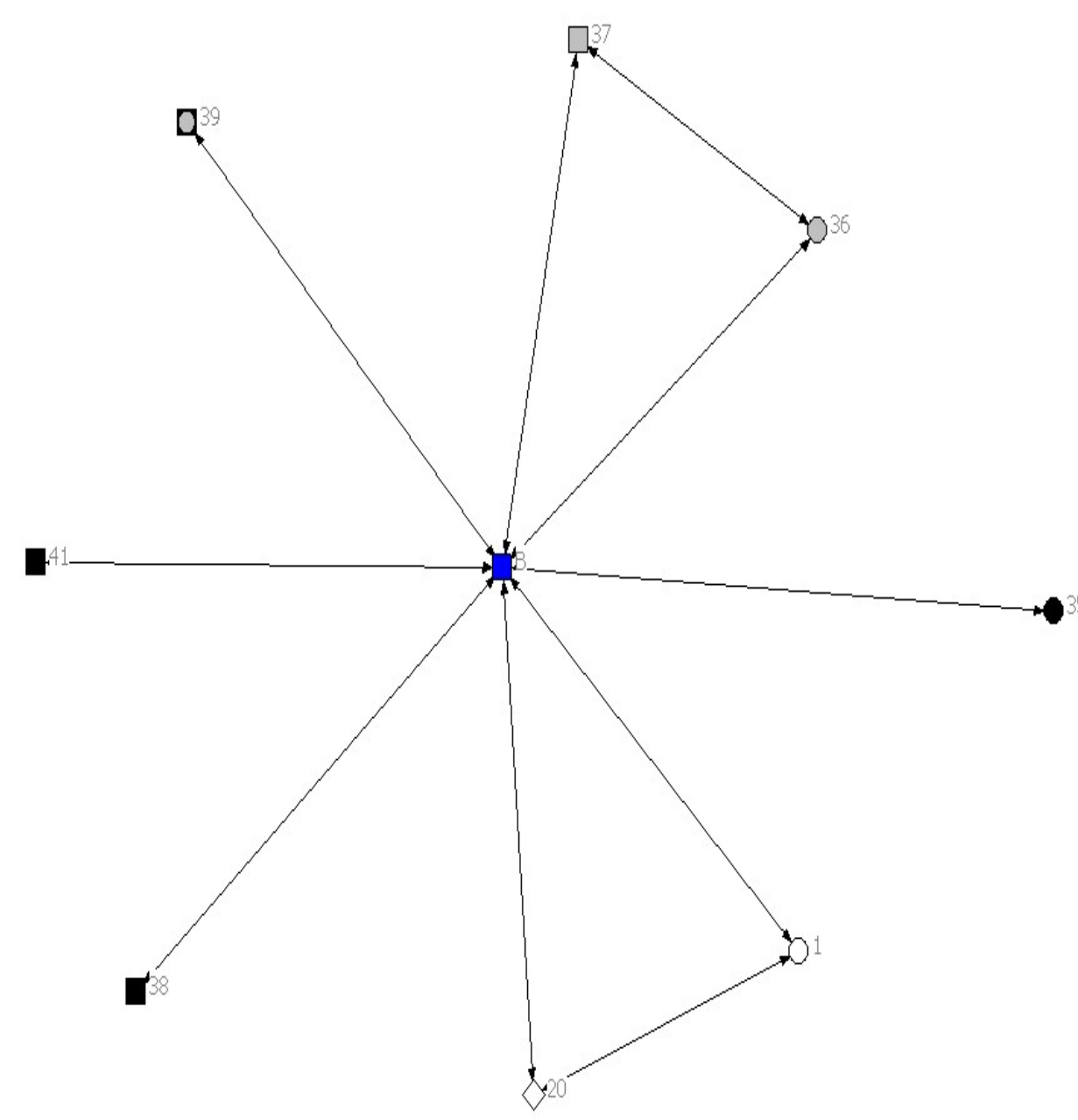


FIRM C

Figure 12 - Potential network:

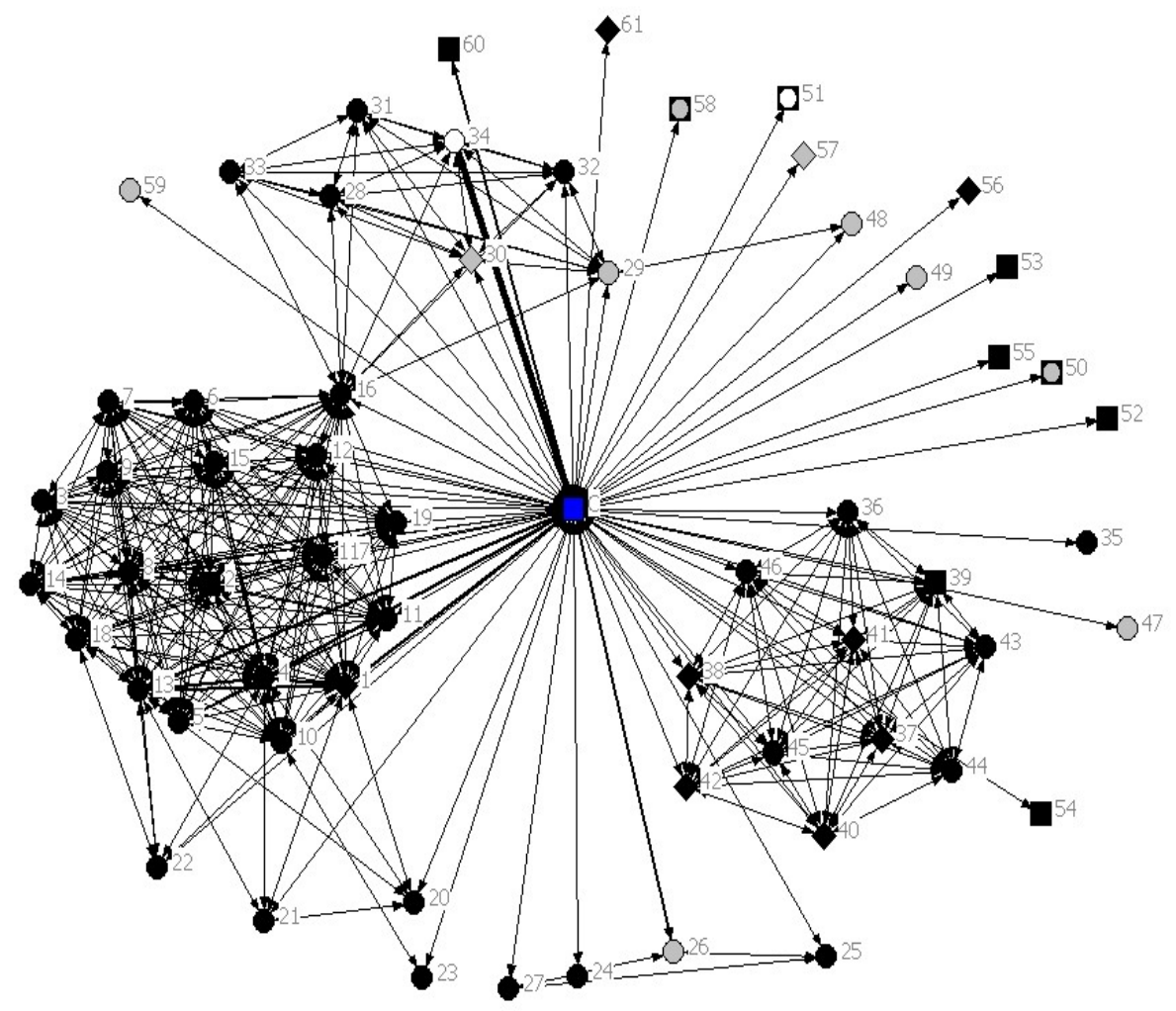

Figure 13 - Network of Innovation:

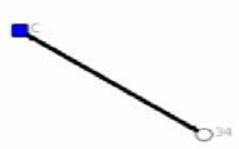

Figure 14 - Network of access and opportunity:

q 
FIRM D

Figure 15 - Potential Network:

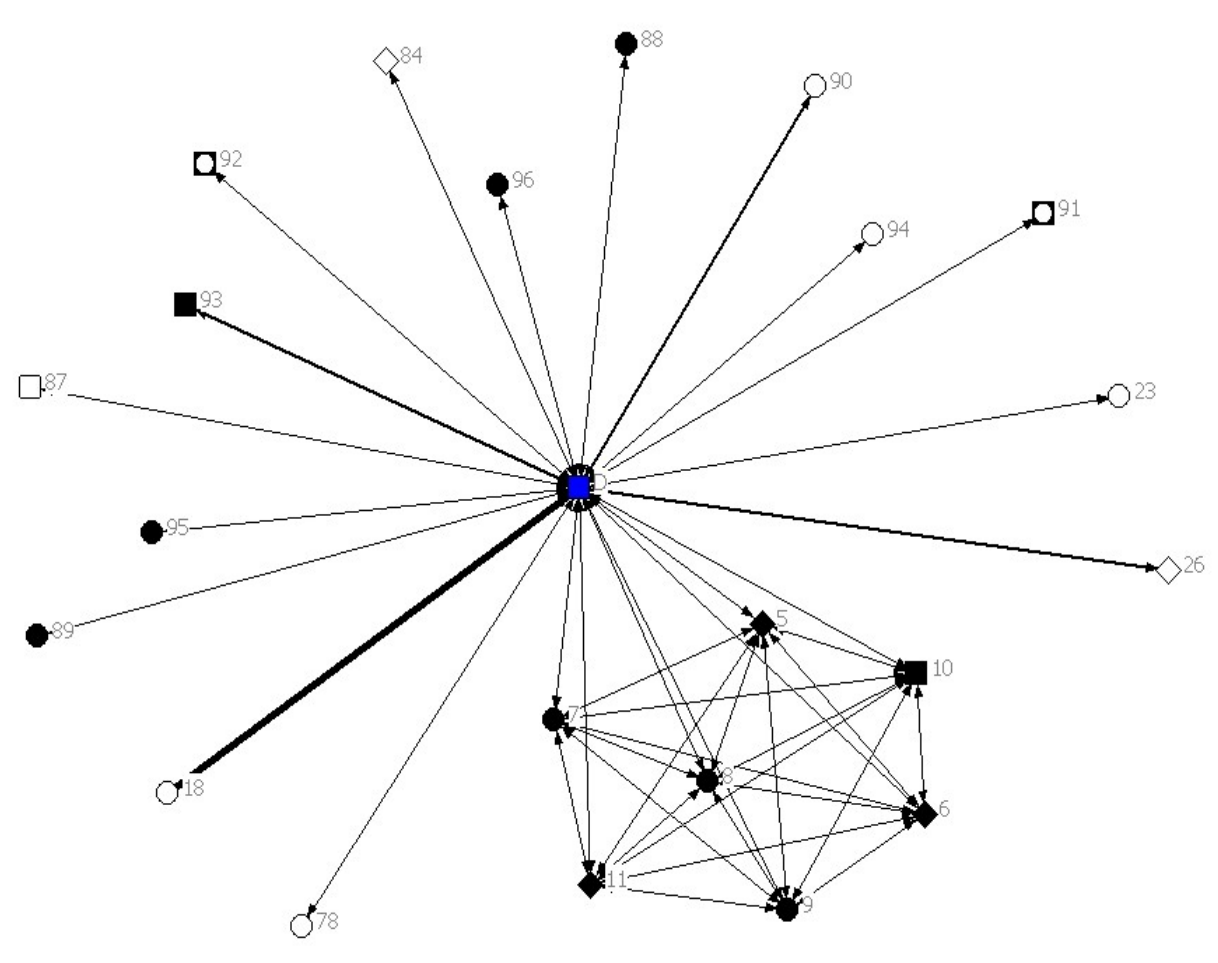

Figure 16 - Network of Access and Opportunity:

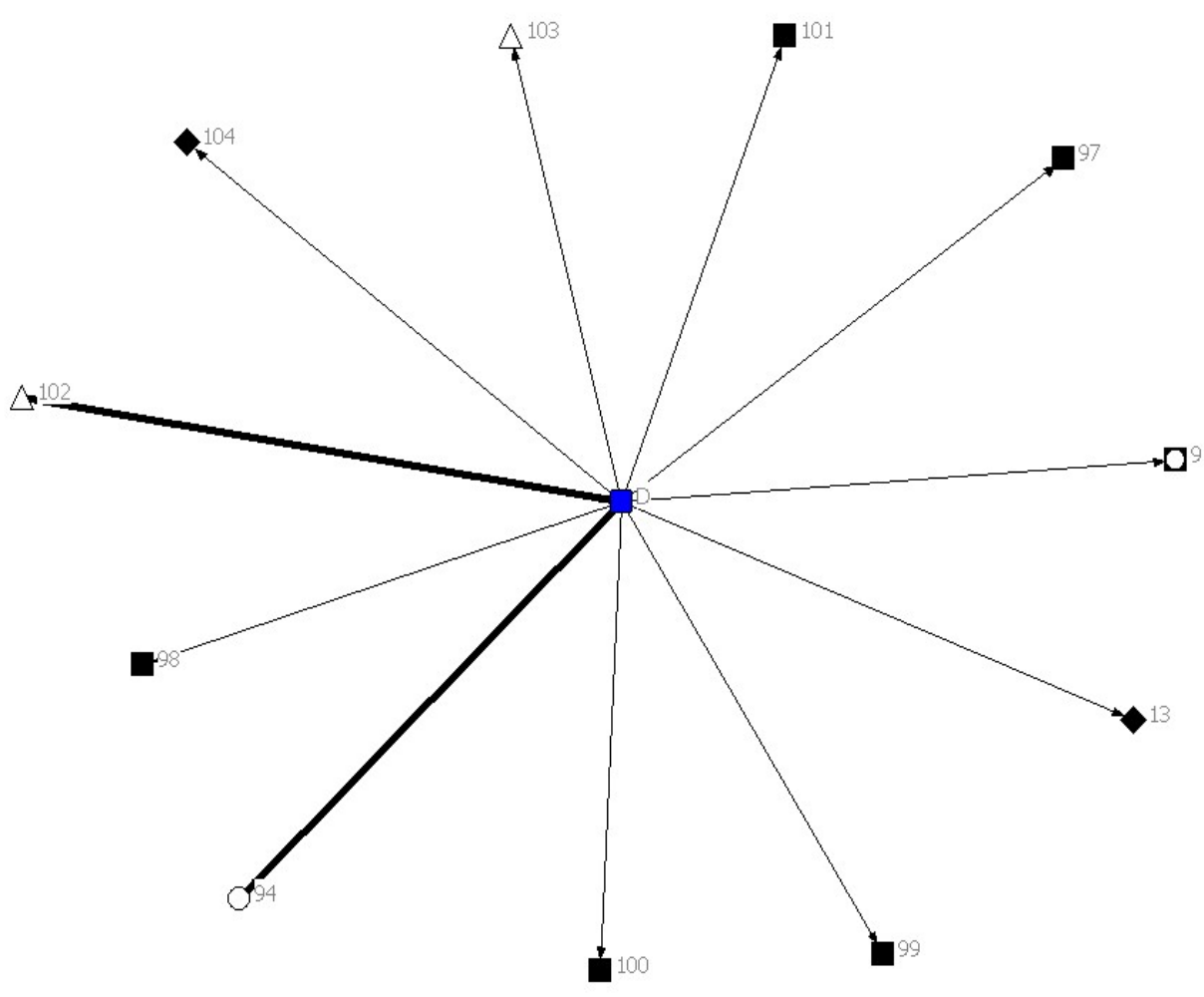


Figure 17 - Network of Innovation:

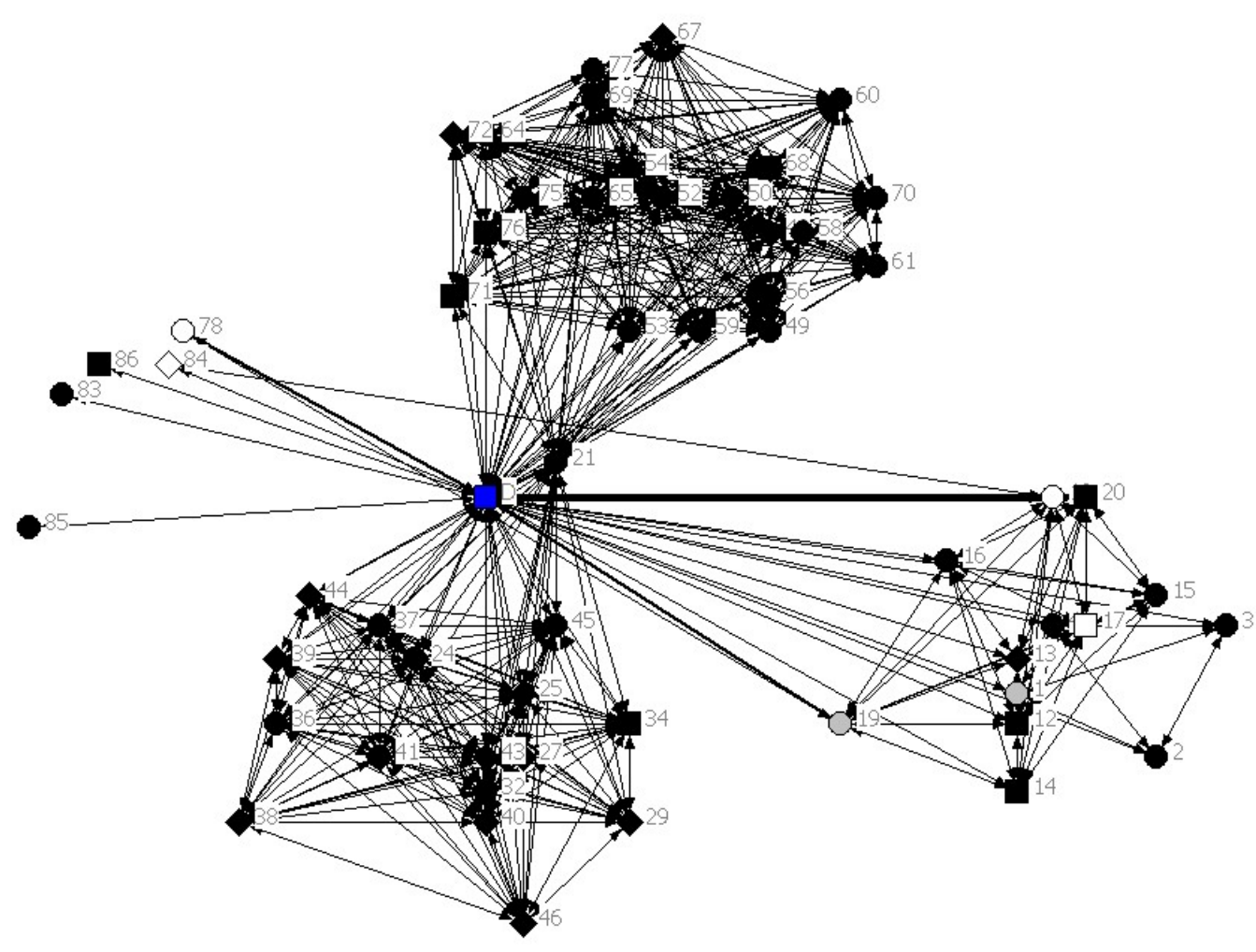

Figure 18 - Network of Power and Influence:

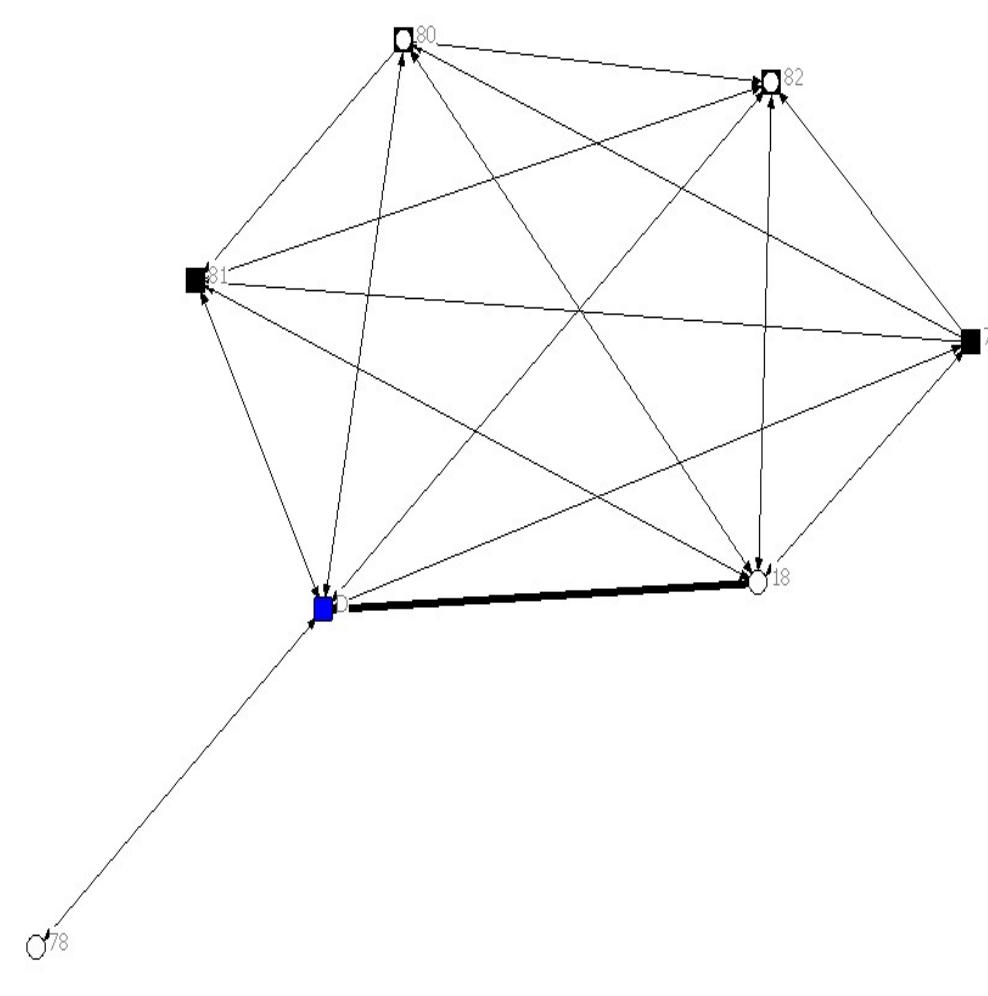

